\title{
Has the Residual Exception Swallowed the Hearsay Rule?
}

\author{
David A. Sonenshein ${ }^{*} \&$ Ben Fabens-Lassen ${ }^{* *}$
}

\section{INTRODUCTION}

In 1982, Professor David Sonenshein was one of the first scholars to analyze the growing body of case law applying the residual exception to the hearsay rule. ${ }^{1}$ His Article-The Residual Exceptions to the Federal Hearsay Rule: Two Exceptions in Search of a Rule (hereinafter "Residual Exceptions") - provided a step-by-step analysis of the elements of the residual exception. ${ }^{2}$ Residual Exceptions surveyed and critiqued the early prevailing interpretations of the rule and demonstrated a growing trend where courts were endorsing interpretations of the exception in a manner inconsistent with the original intent and purpose of the rule. In Residual Exceptions, Professor Sonenshein argued, and some courts agreed, ${ }^{3}$ that the federal courts "have neither interpreted nor applied the

* David A. Sonenshein is the Jack E. Feinberg Professor of Litigation at the Temple University Beasley School of Law.

** Ben Fabens-Lassen received a J.D. from the Temple University Beasley School of Law, where he was Editor-in-Chief of the Temple Law Review. He is currently a law clerk at the United States District Court for the Eastern District of Pennsylvania.

1. David A. Sonenshein, The Residual Exceptions to the Federal Hearsay Rule: Two Exceptions in Search of a Rule, 57 N.Y.U. L. REV. 867 (1982) [hereinafter Residual Exceptions]. For later discussions of the residual exception(s), see Joseph W. Rand, The Residual Exceptions to the Federal Hearsay Rule: The Futile and Misguided Attempt to Restrain Judicial Discretion, 80 GEO. L. J. 873 (1992); James E. Beaver, The Residual Hearsay Exception Reconsidered, 20 FLA. ST. U. L. Rev. 787 (1993); and Roger C. Park, Hearsay, Dead or Alive?, 40 ARIZ. L. ReV. 647 (1998).

2. As originally enacted, there were in fact two residual exceptions to the hearsay rule —one for available declarants and one for unavailable declarants. See FED. R. EvID. 803(24), 804(b)(5) (repealed 1997), FEDERAL RULES OF EVIDENCE 18-19 (1975), reprinted in 4 JAMES F. BAILEY \& Oscar M. Trelles, The Federal Rules of Evidence: Legislative Histories and Related DOCUMENTS (1980). Those rules have been combined, and now the residual exception can be found at Rule 807. FED. R. EVID. 807. There was no substantive change to the underlying law as a result of this amendment to the Federal Rules of Evidence. FED. R. EVID. 804(b)(5) advisory committee's note to 1997 amendments.

3. See, e.g., Commonwealth v. Pope, 491 N.E.2d 240, 244 \& n.9 (Mass. 1986) (quoting Residual Exceptions to support the conclusion that "[w]e do not believe the administration of justice in this Commonwealth would be advanced by adoption of [the residual exception] whose application in practice has been marked by conflicting and illogical results"). 
residual exceptions consistently with their purposes or terms." ${ }^{4}$ The article concluded with a minor amendment to the residual exception that would make the text and judicial interpretations of the exceptions better align with the Congress's intended purpose of the rule in the matter of pretrial notice. $^{5}$

This Article serves to update and expand upon the early but in-depth analysis of the residual exception to the hearsay rule. Although the residual exception began as a matter of federal, rule-based law, state courts and legislatures have also considered, and in some cases rejected, the exception and appropriate scope. Thirty states have adopted a residual exception in their state rules of evidence, including numerous states that have enacted modified or limited versions of the federal exception. ${ }^{6}$ This Article builds on Residual Exceptions by surveying both federal and state cases on the residual exception and comparing the predominant state-law approaches to the admission of residual hearsay under the Federal Rules of Evidence.

Like the original article, this Article traces the variety of approaches courts have adopted when interpreting and analyzing the proper scope of the exception. It begins with a brief overview of the residual exception, examining the origins of the exception and the ensuing judicial liberalization of its requirements. ${ }^{7}$ This Article then analyzes the "trustworthiness," "probativeness," and notice requirements of the exception, ${ }^{8}$ looking at both federal and state interpretations of the rule and offering a critique of a number of judicial interpretations of the Rule. Next, this Article provides an in-depth, fifty-state survey on the residual exception, highlighting the various approaches states use for the admission of residual hearsay. ${ }^{9}$ The Article concludes that among the state courts that have adopted the exception, many have been far more rigorous than their federal counterparts in setting out the markers that trial courts should use to determine the admissibility of residual hearsay. The use of these markers brings more coherence to trial courts' exercise of discretion in discriminating between admissible and inadmissible residual hearsay.

4. Residual Exceptions, supra note 1, at 867.

5. Id. at 901-05 (proposing that the notice provision of the hearsay rule be amended to adopt the "flexible view," which would better serve the underlying purpose of the notice requirement).

6. See infra Appendix.

7. See infra Part II.

8. See infra Part III.

9. See infra Part IV and Appendix. 


\section{THE RESIDUAL EXCEPTION THEN AND NOW}

\section{A. Origins of the Residual Exception: Dallas County and Probative Force of Hearsay}

The residual exception grew out of the Fifth Circuit's 1961 decision in Dallas County v. Commercial Union Assurance Co. ${ }^{10}$ Writing for the court, Judge John Minor Wisdom began, "On a bright, sunny morning, July 7, 1957, the clock tower of the Dallas County Courthouse at Selma, Alabama, commenced to lean, made loud cracking and popping noises, then fell, and telescoped into the courtroom."11 In the case, Dallas County requested for its insurer, Commercial Union Assurance Company, to cover the damage resulting from the collapse of the Dallas County Courthouse clock tower. ${ }^{12}$ At trial, the insurance company contested liability for the resulting damage and claimed that the building was structurally defective. ${ }^{13}$ In support of its claim, the company introduced a nearly sixty-year-old newspaper article about a 1901 fire in the clock tower that ignited when the tower was stricken by lightning. ${ }^{14}$ Despite the County's obvious claim that "[y]ou cannot cross-examine a newspaper," and the court's acknowledgment that the newspaper article did not satisfy any established exception to the hearsay rule, it was admitted into evidence at trial. ${ }^{15}$ The Fifth Circuit upheld the trial court's admission of the article on the grounds that it was sufficiently trustworthy and necessary - that is, the court reasoned that the article was the only evidence available to prove the insurer's claim and it came from an inherently reliable source. ${ }^{16}$

In the same year that Dallas County was announced, renowned evidence professor (and soon-to-be judge) Jack Weinstein published the seminal article Probative Force of Hearsay, in which he espoused his views on how the rules of evidence should address the admission of hearsay evidence. ${ }^{17}$ Judge Weinstein began by examining the three

0. 286 F.2d 388 (5th Cir. 1961).

11. Id. at 390

12. $I d$.

13. $I d$.

14. Id. at 390-91 (discussing the newspaper article at length).

15. Id. at 391-92, 397-98.

16. Id. at 397-98.

17. Jack B. Weinstein, Probative Force of Hearsay, 46 IowA L. Rev. 331 (1961). Judge Weinstein begins the article with a concise description of the hearsay rules' problems: "The present evidence rules fall short of providing a satisfactory solution to the hearsay problem. They exclude 
primary solutions that had been proposed to resolve the hearsay problem-rejecting all three in the process. ${ }^{18}$ Judge Weinstein rejected the two proposals on both ends of the spectrum: admitting hearsay freely and excluding hearsay absolutely. ${ }^{19}$ On the one hand, unrestricted admission of hearsay would undermine the importance of crossexamination to the fact-finding process; ${ }^{20}$ on the other hand, an absolute prohibition on the admission of hearsay failed to account for the "practicalities of our trial practice." ${ }^{21}$ Judge Weinstein then rejected the class-based hearsay exceptions proposed by John Henry Wigmore-the approach codified in the Federal Rules of Evidence. ${ }^{22}$ Such an approach, Judge Weinstein cautioned, "makes admissible a class of hearsay rather than particular hearsay for which, in the circumstances of the case, there is need and assurance of reliability." 23 To Judge Weinstein, it is those two considerations - the necessity of the hearsay to the proponent and reliability of the out-of-court statement - that dictate the probative force of hearsay. ${ }^{24}$

Because all three of those approaches failed to premise admissibility of an out-of-court statement on the probative force of hearsay, Judge Weinstein proposed a fourth approach: "Admission [b]ased [u]pon [p]robative [f]orce [w]ith [p]rocedural [s]afeguards." 25 "[I]t would seem desirable," he argued, "to abandon the class exception system and substitute individual treatment if such a practice were to be combined with advance notice to the opponent when hearsay was to be introduced."26 Under Judge Weinstein's probativeness approach to resolving the hearsay problem, admission would "depend upon probative force weighed against the possibility of prejudice, unnecessary use of

\footnotetext{
evidence that has a higher probative force than evidence they admit. They fail to provide adequate procedural devices to minimize the possibility of misjudging the probative force of hearsay admitted." Id. at 331 .

18. Id. at 334-42. Of note, in 1961 the Uniform Rules of Evidence were in effect. Under the Uniform Rules, "[a]ny . . . evidence tending to impair or support the credibility of the declarant is admissible if it would have been admissible had the declarant been a witness." UNIF. R. EVID. 65 (repealed 1975), UNIFORM RULES OF EVIDENCE 211 (1953), reprinted in 1 BAILEY \& TRELLES, supra note 2.

19. Id. at 334-37.

20. Id. at $334-36$.

21. Id. at 337 .

22. Id. at $337-38$

23. Id. at 337 .

24. See id. at 337-38.

25. Id. at 338 .

26. Id.
} 
court time, and availability of more satisfactory evidence." 27 In order " $[\mathrm{t}] \mathrm{o}$ prevent burdening the trial with a great deal of evidence of small probative force," Judge Weinstein rationalized, "it would be well to permit the court a greater freedom to exclude than it normally exercises." 28 The residual exception to the hearsay rule grew in large part out of this proposal put forth in Judge Weinstein's thoughtprovoking 1961 article. $^{29}$

That same year, the Judicial Conference approved a proposal to draft federal rules of evidence. ${ }^{30}$ By 1965, the Advisory Committee on Rules of Evidence - comprised of scholars, practitioners, and judges (including Judge Weinstein who was appointed to the bench while serving on the Committee)—was established. ${ }^{31}$ The Committee debated at length the requirements for the admission of hearsay under the Federal Rules, and those debates demonstrate how Judge Weinstein's proposal inspired what came to be known as the residual exception. ${ }^{32}$

For instance, in March 1971, the Committee issued its Revised Draft of Proposed Rules of Evidence in which it addressed "the hearsay problem." 33 The Committee explained that it was considering three approaches to hearsay, "[s]ince no one advocates excluding all hearsay." ${ }^{34}$ The three approaches include (1) abolition of the hearsay

27. Id. at 338-39. Judge Weinstein's proposal also contained several procedural requirements, including a pretrial notice requirement, allowance for judges to comment openly on the weight of the evidence, and various precautionary measures related to appellate review. Id. at 338-48.

28. Id. at 338; see id. at 353 ("Exercise of discretion rather than mechanical rules requires more thought and consideration of such factors as surprise, possible prejudice through overestimation of force, and the availability of other evidence more easily assessed.").

29. In 1968, Judge Weinstein gave a speech before the Annual Advocacy Institute in which he proposed seven alternative approaches to the admission of hearsay evidence under the forthcoming Federal Rules of Evidence. As he did in his 1961 article, Judge Weinstein concluded:

[A] recodification and liberalization of the rules of hearsay with an explicit general statement of principle for admitting useful hearsay which does not fall within a specific exception seems preferable. The court should, in addition, be given greater freedom in civil than in criminal cases and in bench than in jury trials to admit hearsay.

Jack B. Weinstein, Alternatives to the Present Hearsay Rules, 44 F.R.D. 375, 388 (1968).

30. Jon R. Waltz, The New Federal Rules of Evidence: An Overview, 52 CHI.-KENT. L. REv. 346, 347 (1975). For a history of the Federal Rules of Evidence, see id. at 346-50. For an early discussion on reading and interpreting the Federal Rules of Evidence, see Edward W. Cleary, Preliminary Notes on Reading the Rules of Evidence, 57 NEB. L. REV. 908 (1978).

31. Waltz, supra note 30 , at 347 \& n.9.

32. See id. at 347-48 (discussing committee process and debate).

33. Comm. on Rules of Practice \& Procedure, Judicial Conference of the U.S., Revised Draft of Proposed Rules of Evidence for the United States Courts and Magistrates, 51 F.R.D. 315, 408-13 (1971).

34. Id. at 409 . 
rule in favor of free admission of all hearsay; (2) Judge Weinstein's proposal to "admit hearsay possessing sufficient probative force, but with procedural safeguards"; and (3) revision of the class-based, commonlaw-hearsay exceptions. ${ }^{35}$ After rejecting the proposal to freely admit all hearsay so as to preserve "the traditional requirement of some particular assurance of credibility as a condition precedent to admitting the hearsay declaration," the Committee turned to Judge Weinstein's proposal. ${ }^{36}$ Expressly citing Probative Force of Hearsay, the Committee began by acknowledging that "[a]bandonment of the system of class exceptions in favor of individual treatment in the setting of the particular case ... has been impressively advocated." 37 Despite the persuasiveness of Judge Weinstein's proposal, the Committee opted to retain the categorical exceptions, subject to subsequent revisions. ${ }^{38}$

In rejecting the all-out-discretionary approach championed by Judge Weinstein in Probative Force of Hearsay, the Advisory Committee contended that such a proposal "involv[es] too great a measure of judicial discretion, minimiz[es] the predictability of rulings, enhanc[es] the difficulties of preparation for trial, add[s] a further element to the already over-complicated congeries of pretrial procedures, and requir[es] substantially different rules for civil and criminal cases." ${ }^{39}$ As a testament to the persuasiveness of Judge Weinstein's original proposal, however, the Committee's Revised Draft included a compromise: the residual exception. ${ }^{40}$ While the residual exceptions in 803(24) and 804(b)(6) (now Rule 807) "do not contemplate an unfettered exercise of judicial discretion," as the Committee observed, "they do provide for treating new and presently unanticipated situations which demonstrate a trustworthiness within the spirit of the specifically stated exceptions." 41

After the Committee submitted the Revised Draft to the Supreme Court, " $[\mathrm{t}]$ he focus for development of a discretionary power to admit hearsay shifted from the courts to Congress." the Court and Congress ensued after the Chief Justice submitted the

35. Id. at 409-10.

36. Id. at 410 .

37. Id.

38. Id. at $410-11$.

39. Id. at 410 .

40. See id. at 411 (discussing the residual exceptions and stating they were "calculated to encourage growth and development in this area of the law, while conserving the values and experience of the past as a guide to the future").

41. Id. at 437 .

42. Residual Exceptions, supra note 1, at 871. 
Proposed Rules to the legislative branch. ${ }^{43}$ Upon receipt of the Proposed Rules, "[i]nfluential members of Congress were displeased with the Supreme Court's inclusion of a date on which the rules would automatically become effective in the absence of congressional disapproval." $"$ Due to the perceived "highhandedness" of the Court, the Proposed Rules spent the next two years working their way through various congressional committees and subcommittees, until President Gerald Ford ultimately signed the Federal Rules of Evidence into law in January $1975 .^{45}$

Based on this history, an early commentator who was intimately familiar with the Rules stated, "While controversial, this residual exception is not likely to be dramatically significant. The preconditions are onerous but beyond that, it is quite difficult to think of many trustworthy types of hearsay that are not already adequately covered by the traditional exceptions to the rule against hearsay." history has profoundly called that prediction into question.

43. See Waltz, supra note 30, at 348-49 (discussing the Rules' progression through Congress).

44. Id. at 348 .

45. See id. at 348-49 ("It is accurate to say that the rules ultimately approved by Congress and signed into law by the President are essentially the rules promulgated by the Supreme Court, with some important exceptions dictated in the main by Congress' disagreement with the Advisory Committee's assessment of the significance of Erie Railroad Co. v. Tompkins, and, regrettably, with a few vexing drafting errors." (footnotes omitted)). The residual exception's history was thoroughly explained in a 1979 Congressional Research Service report:

When the federal rules were considered by the House ... both sections 803(24) and 804(b)(6) ... were deleted. The reasons for this action were stated ... to be that these rules injected too much uncertainty into the law of evidence and impaired the ability of practitioners to prepare for trial.... The Senate, when it took the House passed bill under consideration, reinstated both rules but with changes and additions. The requirement of "comparable" circumstantial guarantees of trustworthiness was changed to "equivalent" guarantees... were added. The Senate amendments to these rules were accepted by the Committee of Conference but only after it incorporated additional requirements concerning prior notice of intent to introduce the evidence. It is rather clear from the Conference Report ... and from discussions on the floor of the House ... that this addition was a compromise to provide the counsel against whom such evidence may be offered a fair opportunity through prior notice to prepare to object to the evidence, to contest its admissibility, and to meet it should it be admitted.

Murl A. Larkin, Cong. Research Serv., Rep. No. 79-94, Residual Exceptions to the HEARsay Rule Under the FEDERAL RULeS OF EVIDENCE 3-4 (1979).

46. Waltz, supra note 30, at 364. See S. REP. No. 93-1277, at 20 (1974), as reprinted in 1974 U.S.C.C.A.N. 7051, 7066 ("The committee does not intend to establish a broad license for trial judges to admit hearsay statements that do not fall within one of the other exceptions.... It is intended that ... the trial judge will exercise no less care, reflection and caution than the courts did under the common law."); see also Waltz, supra note 30, at 346-50 (examining the legislative history of the Rules of Evidence); Residual Exceptions, supra note 1, at 872-75 (examining the legislative history of the residual exception specifically). 


\section{B. Rule 807 and the Judicial Liberalization of the Residual Exception}

As explained by the Supreme Court in 1990, "The residual hearsay exception ... accommodates ad hoc instances in which statements not otherwise falling within a recognized hearsay exception might nevertheless be sufficiently reliable to be admissible at trial." ${ }^{, 47}$ The exception, which applies irrespective of the availability of the hearsay declarant, is currently found at Federal Rule of Evidence 807, which reads as follows:

Under the following circumstances, a hearsay statement is not excluded by the rule against hearsay even if the statement is not specifically covered by a hearsay exception in Rule 803 or 804 : (1) the statement has equivalent circumstantial guarantees of trustworthiness; (2) it is offered as evidence of a material fact; (3) it is more probative on the point for which it is offered than any other evidence that the proponent can obtain through reasonable efforts; and (4) admitting it will best serve the purposes of these rules and the interests of justice. ${ }^{48}$

Additionally, the notice provision of the Rule provides that a "statement is admissible only if, before the trial or hearing, the proponent gives an adverse party reasonable notice of the intent to offer the statement ... so that the party has a fair opportunity to meet it."

The residual exception, as originally enacted by Congress, was intended to embody the Dallas County court's rationale - subject to subsequent fine-tuning by the Advisory Committee and eventually the Senate and House Committees. ${ }^{50}$ Many courts cite the language from the legislative history that the rule was intended to "be used very rarely, and only in exceptional circumstances, ${ }^{, 51}$ but nevertheless end up using the residual exception to freely admit hearsay that fails to fit within a categorical exception for statements clearly contemplated by Congress. ${ }^{52}$

\footnotetext{
47. Idaho v. Wright, 497 U.S. 805, 817 (1990).

48. FED. R. EVID. 807(a).

49. FED. R. EVID. 807(b)

50. Residual Exceptions, supra note 1, at 871-75.

51. S. REP. No. 93-1277, at 20, as reprinted in 1974 U.S.C.C.A.N. at 7066. See, for example, United States v. Bailey's discussion of the Senate Committee report. 581 F.2d 341, 346-47 (3d Cir.

52. E.g., United States v. Peneaux, 432 F.3d 882, 893 (8th Cir. 2005) ("Congress intended the residual hearsay exception to "be used very rarely, and only in exceptional circumstances'...." (quoting S. REP. No. 93-1277, at 20, as reprinted in 1974 U.S.C.C.A.N. at 7066)); United Techs. Corp. v. Mazer, 556 F.3d 1260, 1279 (11th Cir. 2009) ("'Congress intended the residual hearsay exception to be used very rarely, and only in exceptional circumstances,' and it 'appl[ies] only when certain exceptional guarantees of trustworthiness exist and when high degrees of probativeness and
} 1978). 
This trend began shortly after the Federal Rules went into effect. Interestingly enough, in 1976, Judge Weinstein authored two of the earliest residual-exception cases while serving as judge sitting in the District Court for the Eastern District of New York. ${ }^{53}$ As a member of the Advisory Committee who penned the rules, his liberal, well-reasoned interpretation of the residual exception was difficult for the Second Circuit to refute, and it eventually set the stage for a debate regarding the proper interpretation of the residual exception (at least within the Second Circuit). ${ }^{54}$ Over the years, various jurisdictions have abandoned the exceptional-circumstances ideal in favor of a far more liberal approach to residual hearsay than that originally prescribed by Congress. For instance, the narrow exception Congress envisioned is a far cry from the Ninth Circuit's articulation of the exception as one that "exists to provide courts with flexibility in admitting statements traditionally regarded as hearsay but not falling within any of the conventional exceptions." 55

As observed by Professor Roger C. Park, "the consensus of scholarly opinion seems to be that courts construing the residual exceptions have been quite liberal in finding evidence trustworthy enough to be received." 56 And the reason for this appears obvious: while the

necessity are present.", (citations omitted)).

53. United States v. Iaconetti, 406 F. Supp. 554, 558-60 (E.D.N.Y. 1976), aff'd, 540 F.2d 574 (2d Cir. 1976); United States ex rel. Edney v. Smith, 425 F. Supp. 1038, 1055 (E.D.N.Y. 1976), aff'd, 556 F.2d 556 (2d Cir. 1977).

54. Compare Iaconetti, 406 F. Supp. at 559 ("In addition, 'the general purposes of these rules and the interests of justice will best be served by admission of the statement into evidence.' There is a clear conflict of credibility. The jury was entitled to all the help available on the point." (citation omitted) (quoting FED. R. EVID. 803(24)(C))), with United States v. Medico, 557 F.2d 309, 315 (2d Cir. 1977) ("The Committee Advisory Note points out that the cases reveal a hesitancy to admit the statement without more when the bystander's identity is unknown. This may well be the reason Judge Weinstein decided to rely on Rule 804(b)(5). That fact, however, that the statement meets all the specific standards for admissions under 803(1) but fails to meet all the criteria set forth in the supportive judicial rationale surely brings it within the grant of discretion which 804(b)(5) accords to a trial judge, consonant with the legislative purposes which the residual exception was designed to achieve." (citation omitted)). Compare Iaconetti, 406 F. Supp. at 560 ("Although notice was not given in advance of trial, as required by the language of the Rule, allowance must be made for situations like this in which the need did not become apparent until after the trial had commenced."), with United States v. Oates, 560 F.2d 45, 73 n.30 (2d Cir. 1977) ("Our examination of the congressional debates further discloses that the requirement that notice be given in advance of trial was the method selected by the Committee of Conference to prevent abuse of FRE 803(24) and 804(b)(5).").

55. United States v. Valdez-Soto, 31 F.3d 1467, 1471 (9th Cir. 1994).

56. Park, supra note 1, at 651-52 (footnote omitted); see also Beaver, supra note 1, at 790-91 ("The residual hearsay exceptions threaten to swallow the hearsay rule. Since 1975, the use of Rules 803(24) and 804(b)(5), and their state equivalents, have been reported in more than 140 federal cases and in more than ninety state cases. Contrary to the intent of Congress, these figures suggest that the catchall exceptions are being used more generally than in rare and exceptional circumstances." 
applicability of the exception in varying circumstances is a frequent subject of debate, it is undoubtedly clear that the residual exception grants district court judges a tremendous amount of discretion to admit evidence that would not otherwise qualify under a specific hearsay exception laid out in Rule 803 or $804 .^{57}$ For instance, more than thirty years after the rule was enacted, the Ninth Circuit observed that "[o]ur research has disclosed only one instance where a circuit court reversed a district court to require admission of a statement under FRE 807." 58 This deference has led to an interesting patchwork of residual exception case law, whereby the admissibility of hearsay evidence in any given case varies from federal court to federal court based on the peculiar approach followed in a particular jurisdiction. Indeed, U.S. Circuit Courts of Appeals have even carved out specific, categorical types of out-of-court statements that are routinely introduced under the residual exceptionincluding, bank records and other business records, ${ }^{59}$ plea agreements to ponzi schemes, ${ }^{60}$ statements made in furtherance of conspiracies, ${ }^{61}$ and testimony given by child witnesses. ${ }^{62}$

Against this backdrop of differing conclusions on the meaning of the residual exception's elements among jurisdictions, as well as differing judicial philosophies regarding the proper scope of the exception, ${ }^{63}$ Part

(footnotes omitted)).

57. Courts review decisions to admit evidence under the residual exception for abuse of discretion, or clear error. Rivers v. United States, 777 F.3d 1306, 1312 (11th Cir. 2015), cert. denied, 136 S. Ct. 267 (2015). That standard of review, coupled with the harmless error doctrine, makes a successful appellate challenge to the admission of evidence under the residual exception exceedingly rare. See, e.g., id. (noting that courts are "particularly hesitant to overturn a trial court's admissibility ruling under the residual hearsay exception absent a 'definite and firm conviction that the court made a clear error of judgment in the conclusion it reached based upon a weighing of the relevant factors." (quoting Balogh's of Coral Gables, Inc. v. Getz, 798 F.2d 1356, 1358 (11th Cir. 1986))); see also Todd J. Bruno, Say What?? Confusion in the Courts over What Is the Proper Standard of Review for Hearsay Rulings, 18 SUfFOLK J. TRIAL \& APP. ADVOC. 1, 20 (2013) (stating that "many courts still apply the 'abuse of discretion' rubber stamp").

58. United States v. Bonds, 608 F.3d 495, 501 (9th Cir. 2010) (citing United States v. SanchezLima, 161 F.3d 545, 547-48 (9th Cir. 1998)).

59. E.g., United States v. Simmons, 773 F.2d 1455, 1458 (4th Cir. 1985) (discussing use of trace forms as a business record exception to the hearsay rule); infra notes 110-17 and accompanying text.

60. See infra notes $272-81$ and accompanying text.

61. See, e.g., United States v. Hitsman, 604 F.2d 443, 447 (5th Cir. 1979) (discussing statements made in furtherance of a conspiracy).

62. "Courts have employed the exception most extensively in admitting statements made by child witnesses, particularly in sexual abuse cases." 2 KENNETH S. BROUN, MCCORMICK ON EVIDENCE $§ 324$ (7th ed. 2013).

63. In an interesting concurring opinion, Judge Richard Posner advocated for adopting an approach to the admission of hearsay that greatly expands the role of the residual exception. See 
III of this Article explores the elements of the residual exception.

\section{PRevailing InterPRetations of the Key Elements OF THE RESIDUAL EXCEPTION}

The residual exception allows for the admission of hearsay that would not otherwise fall within one of the specific Rule 803 or 804 exceptions to the hearsay rule, so long as the out-of-court statement offered into evidence meets the basic requirements listed in Rule 807.

First, the out-of-court statement must possess "equivalent circumstantial guarantees of trustworthiness." ${ }^{64}$ This is referred to as the trustworthiness requirement. Second, the statement must be "offered as evidence of a material fact." ${ }^{\circ 5}$ Because the Federal Rules of Evidence make relevance a prerequisite to the admission of hearsay statementsand all evidence for that matter-this prong has been referred to as "redundant" and does not appear to carry much weight. ${ }^{66}$ Third, the statement must be "more probative on the point for which it is offered than any other evidence that the proponent can obtain through reasonable

Jeffrey Bellin, The Case for eHearsay, 83 FoRdHAM L. REV. 1317, 1325-26 (2014) (discussing Judge Posner's proposal). This approach is similar to the approach advocated for by Judge Weinstein during his time on the Advisory Committee. Id. at 1326. In a sense, Posner's proposal would make Rule 807 the primary gatekeeper of whether hearsay is reliable, rather than only coming into play when one of the exceptions in Rules 801 to 806 cannot be satisfied. Specifically, Judge Posner proposed the following:

What I would like to see is Rule 807 ("Residual Exception") swallow much of Rules 801 through 806 and thus many of the exclusions from evidence, exceptions to the exclusions, and notes of the Advisory Committee. The "hearsay rule" is too complex, as well as being archaic. Trials would go better with a simpler rule, the core of which would be the proposition (essentially a simplification of Rule 807) that hearsay evidence should be admissible when it is reliable, when the jury can understand its strengths and limitations, and when it will materially enhance the likelihood of a correct outcome.

United States v. Boyce, 742 F.3d 792, 802 (7th Cir. 2014) (Posner, J., concurring).

64. FED. R. EVID. 807(a)(1).

65. FED. R. EVID. 807(a)(2).

66. See Elizabeth DeCoux, Textual Limits on the Residual Exception to the Hearsay Rule: The "Near Miss" Debate and Beyond, 35 S.U. L. REv. 99, 101-02 (2007) (observing that the materiality requirement is redundant, "given that Rules 401 and 402, taken together, provide that evidence which is not material is inadmissible"). Shortly after the residual exception was enacted, Judge Weinstein observed that the materiality requirement "appears to be redundant in light of the requirement in the Fed. R. Evid. that all evidence be relevant, relating to 'a fact of consequence to the determination of the action." Residual Exceptions, supra note 1, at 874 n.46. Judge Weinstein hypothesized, "What is probably meant is that the exception should not be used for trivial or collateral matters." United States v. Iaconetti, 406 F. Supp. 554, 559 (E.D.N.Y.), aff'd, 540 F.2d 574 (2d Cir. 1976). Hawaii specifically omitted the materiality requirement from its state-law residual exception, despite copying the federal rule in all other respects. See infra Appendix. 
efforts." ${ }^{, 7}$ This is referred to as the probativeness requirement. Fourth, admitting the statement must also "best serve the purposes of these rules and the interests of justice." ${ }^{\prime 68}$ This interests-of-justice requirement, while not as divisive as the probativeness and trustworthiness requirements, has raised interesting questions regarding the propriety of admitting hearsay statements in criminal proceedings subject to the limits of the Confrontation Clause of the U.S. Constitution. ${ }^{69}$ Lastly, "before the trial or hearing," the offering party must "give[] an adverse party reasonable notice of the intent to offer the statement and its particulars ... so that the party has a fair opportunity to meet it."70 This is referred to as the notice requirement. The following Parts of this Article, in turn, address the varying interpretations of each of the requirements of the residual exception.

\section{A. Trustworthiness}

Evidence admitted under the residual exception must be trustworthy; more specifically it must possess "circumstantial guarantees of trustworthiness" equivalent to the established hearsay exceptions found in Rules 803 and $804 .^{71}$ Federal courts consider a variety of factors when determining whether hearsay is sufficiently trustworthy to be admitted under the residual exception. In Rivers $v$. United States, Judge Eduardo Robreno, ${ }^{72}$ sitting by designation with the Eleventh Circuit, thoroughly examined the varying approaches to trustworthiness in federal courts. ${ }^{73}$

\footnotetext{
67. FED. R. EVID. 807(a)(3).

68. FED. R. EVID. 807(a)(4).

69. While the interests-of-justice requirement at times raises interesting discussions of constitutional law, the requirement is also arguably redundant:

[T] he statement must serve the purposes of the rules of evidence and the interests of justice - also somewhat redundant, given the requirements of Rule 102 that all the rules should be construed to secure "fairness in administration and promotion of the growth and development of the law of evidence to the end that the truth may be ascertained and proceedings justly determined."

DeCoux, supra note 66, at 102. Accordingly, this Article primarily focuses on the probativeness, trustworthiness, and notice requirements of the residual exception. See infra Part III.

70. FED. R. EVID. 807(b).

71. FED. R. Evid. 807(a)(1); see Anthony Bocchino \& David Sonenshein, Rule 804(B)(6)-The Illegitimate Child of the Failed Liaison Between the Hearsay Rule and Confrontation Clause, 73 Mo. L. REV. 41, 72 (2008) ("The residual exception of Rule 807, as did its predecessor rules, invites the trial judge to engage in a kind of balancing that implicates both the necessity and trustworthiness of the proposed evidence. That balancing is most likely to result in a fair determination of the admissibility of statements for which no specific exception exists.").

72. Senior United States District Judge for the Eastern District of Pennsylvania.

73. 777 F.3d 1306, 1315 (11th Cir.), cert. denied, 136 S. Ct. 267 (2015).
} 
Judge Robreno detailed some of the prevailing trustworthiness considerations federal courts consider: (1) "the circumstances in which the declarant made the statement and the incentive he had to speak truthfully or falsely;" (2) "the totality of the circumstances surrounding the making of the statement and those rendering the declarant particularly worthy of belief;" (3) "whether the declarant had "clear motivation' to lie or mislead;" and (4) "whether the statement concerned facts of which the declarant had personal knowledge." 74 He observed that courts in the Seventh Circuit, in addition to considering the declarant's motivation, knowledge, and qualifications, also consider "the existence of corroborating evidence." 75 In light of these factors, and the following cases, the federal courts appear to take a holistic approach to trustworthiness, focusing primarily, but not exclusively, on the circumstances surrounding the making of the statement offered under the residual exception.

Case law demonstrates that there are differing jurisdiction-specific views on what is required for evidence to be sufficiently trustworthy to be admitted pursuant to Rule 807 . The requirement has also raised some interesting legal debates. For instance, does the introduction of evidence that corroborates the residual hearsay suffice to make the proffered outof-court statement trustworthy? ${ }^{76}$ Alternatively, should courts confine their trustworthiness analysis by examining only the circumstances surrounding the making of the statement? $?^{77}$ Finally, if a proffered hearsay statement meets most, but not all, of the requirements to satisfy one of the established hearsay exceptions, can it be admitted as "equivalent" under the "near-miss" theory of the residual exception? ${ }^{78}$

\section{Corroboration and the Confrontation Clause}

Residual Exceptions examined the difference between ascertaining trustworthiness by examining the circumstances surrounding the making of an out-of-court statement and by examining extrinsic guarantees of trustworthiness. ${ }^{79}$ After analyzing the breadth of residual exception case

74. Id. (citations omitted).

75. Id. (citing United States v. Hall, 165 F.3d 1095, 1111 (7th Cir. 1999)). See infra Part III.A.1 for a discussion of corroboration.

76. See infra Part III.A.1.

77. See infra Part III.A.2.

78. See infra Part III.A.3.

79. See generally Residual Exceptions, supra note 1. 
law, the author identified three prevailing tests for examining trustworthiness: (1) "[o]ne test measures trustworthiness at the time of trial by analyzing only factors extrinsic to the evidence itself;" second standard considers the circumstances surrounding the making of the out-of-court statement as well as extrinsic corroboration to determine the reliability of the hearsay;" ${ }^{81}$ and (3) "[a] third standard looks only to the circumstances surrounding the making of the out-of-court statement and does not consider extrinsic corroboration to gauge trustworthiness." ${ }^{, 82}$ Ultimately, Residual Exceptions posited that the third standard was the only one that could be squared with the history of the residual exception, concluding that "[c]orroborating evidence ... should not be a factor in the analysis" because, as with all of the historical, categorical exceptions, "only the circumstances of the making should be considered in determining whether hearsay is admissible under the residual exceptions." ${ }^{, 83}$ In the years that have followed there has been considerable debate regarding the relevance of corroboration evidence when determining the trustworthiness of hearsay evidence.

Moreover, Residual Exceptions pointed out a basic and rather obvious reason as to why it is inappropriate to consider corroboration in the residual exception calculus - if there is corroboration, then there is no significant need for the purported residual hearsay since there is other evidence available on point. ${ }^{84}$ If there is corroboration, the probativeness requirement of Rule 807 is not met unless the proffered hearsay is the most probative evidence available on the point for which it is offered. Therefore, if a court chooses to use corroboration as a trustworthiness metric, then it must indulge in a weighing process to determine that the proffered hearsay is somehow more probative than the corroboration. To date, no court that has used corroboration to demonstrate trustworthiness has ever weighed the probative value of the hearsay against the probative value of the corroboration. As Dallas County and Rule 807 have made clear, admissible residual hearsay must be both reliable and necessary. Corroboration, by definition, cuts against necessity.

80. Id. at 876. "Several factors are frequently cited in support of findings that circumstances at the time of trial provide guarantees of trustworthiness. (1) The availability of the declarant[;] (2) [c]orroboration of the statement by other evidence[; and] (3) [t]he declarant's admission at trial of having made the hearsay statement." Id. at $876 \mathrm{n} .55$ (citations omitted).

81. Id. at 876-77; see also id. at 881-83.

82. Id. at 877; see also id. at 883-85; Huff v. White Motor Corp., 609 F.2d 286, 292 (7th Cir. 1979) (discussing elements needed to make evidence trustworthy).

83. Residual Exceptions, supra note 1, at 884.

84. Id. at 879-80. 
The Supreme Court took the opportunity to discuss corroboration evidence in Idaho $v$. Wright, ${ }^{85}$ albeit in a slightly different context. Given the relatively unchecked discretion granted to district judges to admit evidence under the residual exception, the Supreme Court has rarely had the opportunity to clarify its scope and meaning. The Court has, however, interpreted the Confrontation Clause of the Sixth Amendment, which imposes substantive limitations on the introduction of hearsay evidence in criminal trials. In Wright, the Court addressed those constitutional restrictions on the admission of certain out-of-court statements against a criminal defendant, holding that they must bear "indicia of reliability." ${ }^{86}$ Indicia of reliability is evidence that either "falls within a firmly rooted hearsay exception" or possesses "particularized guarantees of trustworthiness." "circumstantial guarantees of trustworthiness" required under Rule 807, yet it is more stringent; the Confrontation Clause "bars the admission of some evidence that would otherwise be admissible under an exception to the hearsay rule." ${ }^{88}$ Ultimately, the Court held that hearsay statements of a child victim lacked the necessary "particularized guarantees of trustworthiness" to satisfy Confrontation Clause scrutiny. ${ }^{89}$

In dicta, the Supreme Court took the opportunity to discuss the trustworthiness of evidence admitted under the residual exception. The Supreme Court explained that, "almost by definition," out-of-court statements that are admitted under the residual exception, "do not share the same tradition of reliability that supports the admissibility of

85. 497 U.S. 805 (1990).

86. Id. at 822. The indicia-of-reliability standard for the admission of hearsay under the Confrontation Clause was originally announced in Ohio v. Roberts, 448 U.S. 56, 66 (1980). Of note, in 2004 the Court overruled the indicia-of-reliability standard announced in Roberts. Crawford v. Washington, 541 U.S. 36, 68-69 (2004) ("[T]he only indicium of reliability sufficient to satisfy constitutional demands is the one the Constitution actually prescribes: confrontation."). The Court in Crawford held the constitutional right to confrontation prevents testimonial hearsay statements from being introduced against a criminal defendant unless the witness is unavailable and the defendant had a prior opportunity for cross-examination. Id. at 53-54; see also Ohio v. Clark, $135 \mathrm{~S}$. Ct. 2173, 2179 (2015) (discussing the standard post-Crawford). While the standard originally announced in Ohio v. Roberts no longer prevails, the Court's discussion of how to discern the trustworthiness of hearsay is useful when assessing the proper scope and meaning of the residual exception.

87. Wright, 497 U.S. at 815 (quoting Roberts, 448 U.S. at 66).

88. Id. at 814. The Court has been "careful not to equate the Confrontation Clause's prohibitions with the general rule prohibiting the admission of hearsay statements," meaning the Sixth Amendment. Id.

89. Id. at 827 . 
statements under a firmly rooted hearsay exception."90 The Court's approach in Wright exemplifies a preference for examining the totality of the circumstances surrounding the making of a statement when determining its trustworthiness. In particular, the Court offered the following example to illustrate the problem with using corroborating evidence to prove trustworthiness:

A statement made under duress ... may happen to be a true statement, but the circumstances under which it is made ... may even be such that the declarant is particularly unlikely to be telling the truth. In such a case, cross-examination at trial would be highly useful to probe the declarant's state of mind when he made the statements; ... evidence tending to corroborate the truth of the statement would be no substitute for cross-examination of the declarant at trial. ${ }^{91}$

This example illustrates that relying on corroborating evidence is often inconsistent with the underlying requirement that hearsay be inherently trustworthy. The Court also identified another flaw in using corroborating evidence to prove the trustworthiness of the circumstances surrounding the making of an out-of-court statement-bootstrapping (i.e., the process of admitting hearsay evidence based on previously admitted hearsay). ${ }^{92}$ In light of these concerns, the Court expressly rejected the use of corroborating evidence to show particularized guarantees of trustworthiness under the Confrontation Clause. ${ }^{93}$ Nonetheless, as explained in the following Part, both state and federal courts differ widely on the weight they afford corroborating evidence when admitting residual hearsay. ${ }^{94}$

\footnotetext{
90. Id. at 817 .

91. Id. at $822-23$.

92. Id. at 823 ("[T] 'particularized guarantees of trustworthiness' would permit admission of a presumptively unreliable statement by bootstrapping on the trustworthiness of other evidence at trial ....”).

93. Id. at 819 ("We agree that 'particularized guarantees of trustworthiness' must be shown from the totality of the circumstances, but we think the relevant circumstances include only those that surround the making of the statement and that render the declarant particularly worthy of belief.").

94. See, e.g., United States v. Mokol, 939 F.2d 436, 440 (7th Cir. 1991) ("“[]n cases where the testimony is offered for a limited purpose, corroboration need not be great. But where the testimony is critical to the case, the trial court may require a high degree of corroboration." (citations omitted)); United States v. Bailey, 581 F.2d 341, 349 (3d Cir. 1978) (“[T]he trustworthiness of a statement should be analyzed by evaluating not only the facts corroborating the veracity of the statement, but also the circumstances in which the declarant made the statement and the incentive he had to speak truthfully or falsely."); United States v. West, 574 F.2d 1131, 1135 (4th Cir. 1978) ("The corroborative circumstances and verification procedures lend to his grand jury testimony a degree of trustworthiness probably substantially exceeding that inherent in dying declarations, statements
} 
2. Totality of the Circumstances Approach to Determining Trustworthiness Under the Residual Exception

Aside from the constitutional constraint on the introduction of hearsay against a criminal defendant, there is no prohibition on the consideration of corroborating evidence under Rule 807. Nonetheless, following the Supreme Court's lead in Wright, many courts have been suspicious of the use of corroborating evidence to prove circumstantial guarantees of trustworthiness. This is due in part to the fact that the use of corroborating evidence to find residual hearsay sufficiently trustworthy is internally inconsistent with the probativeness requirement of the residual exception. ${ }^{95}$ The probativeness requirement generally assumes a lack of corroboration-thus creating the need to rely on the residual exception. If evidence is introduced at trial that corroborates the substance of hearsay offered under the residual exception, that evidence also tends to cut against the notion that the hearsay should come in under the residual exception because it is "more probative." For this reason, and as explained in Residual Exceptions, the view most consistent with the language of the Rule requires that the trustworthiness analysis be based "solely $\mathrm{o}[\mathrm{n}]$ the circumstances at the time of the making of the statement." 96

Among the states that have a residual hearsay exception in their rules of evidence, the prevailing state-law approach to determining trustworthiness is for the trial court to take a holistic approach, considering a variety of factors in light of all of the evidence. In some states these factors are expressly mandated by statute, while in others, trustworthiness is a term of art developed through judicial gloss. These factors often vary, but state courts generally engage in a fact-specific

against interest, and statements of personal or family history . ..."); United States v. McGrath, 39 M.J. 158, 166 (C.M.A. 1994) ("We have previously sided with those courts holding that corroboration by other evidence is one of the means by which hearsay evidence can be tested for trustworthiness.").

95. See Residual Exceptions, supra note 1, at 883 ("[A]ny view of trustworthiness which utilizes corroboration to measure trustworthiness under the residual exceptions misconstrues the rule.").

96. Id. at 883 (citing Huff v. White Motor Corp., 609 F.2d 286 (7th Cir. 1979), as an example of this approach to trustworthiness); see also Rivers v. United States, 777 F.3d 1306, 1314-15 (11th Cir. 2015) ("By requiring hearsay admitted under the residual exception to have circumstantial guarantees of trustworthiness that are like the guarantees of the specific exceptions, Rule 807 is clearly concerned, first and foremost, about whether the declarant originally made the statements under circumstances that render the statements more trustworthy."), cert. denied, 136 S. Ct. 267 (2015). 
inquiry looking at the totality of the circumstances surrounding the making of the out-of-court statement when assessing trustworthiness. ${ }^{97}$ The Supreme Court of Nebraska, like other state courts, has also stressed the importance of examining the nature of the statement itself. ${ }^{98}$ However, other courts, like the Oklahoma Court of Criminal Appeals, have instructed trial courts to consider "facts corroborating the veracity of the statement, circumstances in which the declarant made the statement and the incentive he or she had to speak truthfully or falsely." $" 99$ Of note, it seems that many states allow corroboration to be considered when determining trustworthiness under the residual exception; however, they only do so within the bounds of Wright and as one of multiple factors. ${ }^{100}$ In state court, corroboration is still available to demonstrate trustworthiness for residual exception purposes, as part of a totality-ofthe-circumstances approach to trustworthiness.

Likewise, the Military Commissions Act of 2009 expressly instructs military judges to consider corroboration in determining the admissibility of residual hearsay at military proceedings. For an out-of-court statement to be admitted at military proceedings, a military judge must "tak[e] into account all of the circumstances surrounding the taking of the statement, including the degree to which the statement is corroborated, the indicia of reliability within the statement itself, and whether the will of the declarant was overborne."101 In light of those considerations, the court must make four affirmative findings:

(I) the statement is offered as evidence of a material fact;

(II) the statement is probative on the point for which it is offered;

(III) direct testimony from the witness is not available as a practical matter, taking into consideration the physical location of the witness,

97. See infra Part IV for a survey of state approaches to the residual exception.

98. State v. Phillips, 840 N.W.2d 500, 518 (Neb. 2013) (considering (1) "whether the statement is oral or written"; (2) "whether a declarant had a motive to speak truthfully or untruthfully, which may involve an examination of the declarant's partiality and the relationship between the declarant and the witness;" (3) "whether the statement was made under oath"; (4) "whether the statement was spontaneous or in response to a leading question or questions"; (5) "whether a declarant was subject to cross-examination when the statement was made"; and (6) "whether a declarant has subsequently reaffirmed or recanted the statement.").

99. West v. State, 798 P.2d 1083, 1087 (Okla. Crim. App. 1990); see also OKLA. Stat. AnN. tit. 12, § 2804.1 (West 2009).

100. See infra note 400 for Colorado's and North Carolina's residual-exception, trustworthiness factors, which both consider corroboration.

101. 10 U.S.C. $\$ 949 a(b)(3)(D)(i i)(2012)$. 
the unique circumstances of military and intelligence operations during hostilities, and the adverse impacts on military or intelligence operations that would likely result from the production of the witness; and

(IV) the general purposes of the rules of evidence and the interests of justice will best be served by admission of the statement into evidence. $^{102}$

Interestingly enough, while mirroring the federal rule in many regards, Congress chose to exclude any mention of "equivalent guarantees of trustworthiness" from the military tribunal's residual exception but explicitly added "corroboration." 103

For instance, in United States v. Turner, the Third Circuit adopted a somewhat cautious approach to using corroboration evidence to satisfy the Rule 807 trustworthiness requirement. ${ }^{104}$ Specifically, the court addressed whether corroborating evidence can be used to prove whether hearsay contained in a document can be admitted under the residual exception. ${ }^{105}$ After observing that trustworthiness is a "highly factspecific inquiry," 106 the court affirmatively stated that a "district court may not rely exclusively on corroborating evidence" when determining a document's trustworthiness under Rule 807. ${ }^{107}$ Though Rule 807 is less restrictive than the Confrontation Clause when it comes to corroborating evidence, courts still acknowledge the concerns inherent in using corroboration evidence to prove trustworthiness. ${ }^{108}$

Despite the semi-bright-line rule prohibiting exclusive reliance on corroboration evidence announced in Turner, the Third Circuit still managed to carve out a category of hearsay that is inherently trustworthy.

\footnotetext{
102. Id. § 949a(b)(3)(D)(ii)(I)-(IV).

103. Id. $\S 949 \mathrm{a}(\mathrm{b})(3)(\mathrm{D})(\mathrm{ii})$. The Military Commissions Act also contains a notice provision: the proponent of the evidence makes known to the adverse party, sufficiently in advance to provide the adverse party with a fair opportunity to meet the evidence, the proponent's intention to offer the evidence, and the particulars of the evidence (including information on the circumstances under which the evidence was obtained). Id. $\S 949 \mathrm{a}(\mathrm{b})(3)(\mathrm{D})(\mathrm{i})$.

104. United States v. Turner, 718 F.3d 226, 233-35 (3d Cir. 2013).

105. Id. at 233 .

106. Id. (citing United States v. Wright, 363 F.3d 237, 246 (3d Cir. 2004)).

107. Id. at 233-34 (emphasis added).

108. Compare id. (proscribing only exclusive dependence on corroborating evidence), with United States v. Mokol, 939 F.2d 436, 439-40 (7th Cir. 1991) (tying required amount of corroborating evidence to importance of hearsay testimony).
} 
Turner was charged with conspiracy to defraud the IRS. ${ }^{109}$ At trial, the district court used Rule 807 to admit a variety of bank records that were seized from a co-conspirator's office. ${ }^{110}$ Turner challenged the admission of the documents, arguing that the government did not prove trustworthiness because the declarants were unknown. ${ }^{111} \mathrm{He}$ also argued that the court improperly relied on corroborating evidence alone when holding that the records possessed circumstantial guarantees of trustworthiness. ${ }^{112}$ In upholding the district court's decision to admit the records, the Third Circuit reasoned that bank records "provide circumstantial guarantees of trustworthiness because the banks and their customers rely on their accuracy in the course of their business." 113 The court in Turner seemed to imply that bank records could come in under Rule 807 because they are inherently trustworthy. Of note, the Turner court also stressed that the district court had relied on more than just corroborating evidence in finding the evidence trustworthy under Rule 807. ${ }^{114}$

The admission of bank records and similar business documents under the residual exception appears to be a growing trend. Outside the Third Circuit, other federal circuit courts have upheld the admission of bank records under the residual exception. While Turner involved domestic bank records, the Fifth Circuit held that foreign bank records are also inherently trustworthy due to customer reliance on their accuracy. ${ }^{115}$ In both of these cases the records were admitted under Rule 807 because, for one reason or another, they could not meet the business records exception in Rule 803(6). ${ }^{16}$ In fact, the First Circuit even upheld the

109. Turner, 718 F.3d at 228, 230.

110. Id. at $229-30$.

111. Id. at 234 .

112. Id. The Third Circuit's clear-error standard of review, id. at 233, seems inconsistent with other circuits that review Rule 807 decisions using an abuse-of-discretion standard. See, e.g., United States v. Wilson, 249 F.3d 366, 374-75 (5th Cir. 2001) ("We review evidentiary rulings of the district court for abuse of discretion." (citing United States v. Phillips, 219 F.3d 404, 409 (5th Cir. 2000))), abrogated on other grounds by Whitfield v. United States, 543 U.S. 209 (2005).

113. Turner, 718 F.3d at 234 (quoting United States v. Pelullo, 964 F.2d 193, 202 (3d Cir. 1992)).

114. Id. at 235. According to the court, the district court also considered "(1) the appearance of the records, including their internal consistency; (2) the contents of the records; and (3) the circumstances surrounding the discovery of the records." $I d$.

115. Wilson, 249 F.3d at 374-76.

116. See Karme v. Comm'r, 673 F.2d 1062, 1064 (9th Cir. 1982) (noting that despite the fact "documents were not brought within the Fed. R. Evid. 803(6) 'business records' exception to the hearsay rule because Lynch was not a 'custodian or other qualified witness' ... Fed. R. Evid. 803(24) [the prior residual exception] provides another exception to the hearsay rule."). 
admission of a bank record under the residual exception despite stating unequivocally that "the district court acted under the "wrong' rule"meaning that the documents should not have been admitted under the business records exception. ${ }^{117}$ In a sense, in the event that bank records cannot be admitted under the business records exception, district judges still can do no wrong by admitting bank records under the residual exception.

While the corroboration debate continues, the foregoing cases demonstrate that corroboration should not be the key to the trustworthiness determination. ${ }^{118}$ In deciding on trustworthiness, federal courts are generally more concerned with the circumstances surrounding the making of a statement than corroborating evidence. In that sense, the Rule 807 trustworthiness analysis usually reflects case-by-case analysis of the facts surrounding the statement based on common sense reliability considerations. For instance, in United Technologies Corp. v. Mazer, a case involving a conspiracy to steal confidential airplane-engine blueprints, the Eleventh Circuit addressed the trustworthiness of "unsworn, unattested statements" made in a government investigative report under the residual exception. ${ }^{119}$ The Eleventh Circuit upheld the district court's ruling that the statements were inadmissible under the residual exception. ${ }^{120}$ After observing that Congress intended Rule 807 to be "used very rarely, and only in exceptional circumstances," 121 the court examined the trustworthiness requirement in the case before it. ${ }^{122}$ The court noted that despite the fact that the declarant had submitted to a government interview under a proffer agreement, any declarant that is the target of a criminal investigation has "ample motivation to implicate others (even falsely)."123 The court accordingly held that the hearsay

117. United States v. Nivica, 887 F.2d 1110, 1127 (1st Cir. 1989); see also Santa Barbara Capital Mgmt. v. Nielson (In re Slatkin), 525 F.3d 805, 811-13 (9th Cir. 2008) (upholding the introduction of a plea agreement to participation in a ponzi scheme in a civil case suing the proponent of the scheme under Rule 807 despite the district court's failure to specify which hearsay exception applied).

118. Contra Rivers v. United States, 777 F.3d 1306, 1316 (11th Cir.) (citing a lack of corroborating evidence to support the holding that certain statements "lack equivalent circumstantial guarantees of trustworthiness and that it was error for the district court to admit them under Federal Rule of Evidence 807”), cert. denied, 136 S. Ct. 267 (2015).

119. United Techs. Corp. v. Mazer, 556 F.3d 1260, 1279 (11th Cir. 2009).

120. Id.

121. Id. (quoting United States v. Ingram, 501 F.3d 963, 967 (8th Cir. 2007), vacated by 555 U.S. $1132(2009))$.

122. Id.

123. Id.; see also United States v. Dent, 984 F.2d 1453, 1460 (7th Cir. 1993) ("Nor do we find that Dent's exculpatory statements made to his lawyer have any 'guarantees of trustworthiness' as 
statements lacked the requisite "equivalent circumstantial guarantees of trustworthiness." $" 124$

United States v. Bonds, a Ninth Circuit case, also demonstrates the practical totality approach employed by courts when examining trustworthiness under the residual exception. ${ }^{125}$ There, the defendant was Barry Lamar Bonds, Major League Baseball's all-time career home run leader, who was prosecuted by the federal government for perjury after testifying under oath that he had never taken steroids. ${ }^{126}$ In order to prove its case, the government had to prove that the steroid-positive blood and urine samples it had recovered from the now-infamous BALCO laboratories actually belonged to Bonds. ${ }^{127}$ The government had recovered BALCO records confirming that the samples belonged to Bonds. ${ }^{128}$ Originally the government sought to prove its case with the records, and by calling Bonds's trainer, Greg Anderson, who had allegedly brought the samples to BALCO. ${ }^{129}$ Ultimately, because Anderson refused to testify (and went to jail for contempt), ${ }^{130}$ the government was forced to prove its case through a BALCO employee who allegedly received the samples from Anderson and who would testify to that effect. ${ }^{131}$ The district court ruled that Anderson's out-ofcourt statements could not be admitted to establish the truth of the matter they asserted - that the positive blood samples were in fact drawn from Bonds, which leads to the conclusion that Bonds lied when he testified

required for admission under this rule." (citing United States v. Romo, 914 F.2d 889, 896 (7th Cir. 1990))), abrogated on other grounds by Crawford v. Washington, 541 U.S. 36 (2004).

124. Mazer, 556 F.3d at 1279.

125. United States v. Bonds, 608 F.3d 495, 500-02 (9th Cir. 2009).

126. Id. at 497. This is the same Barry Bonds who hit the peak of his career in his late thirties, and whose head and chest grew exponentially during the later half of his career (circumstantial evidence, of course).

127. $I d$.

128. Id. at 498 .

129. Id.

130. For baseball fans who followed the Bonds saga, the case has a fascinating statement of facts. For instance, the court observed the following about Bonds's relationship with Anderson:

Bonds admitted to paying Anderson $\$ 15,000$ a year for training. Bonds stated that this payment was not formally agreed to. Rather, Bonds contended that he "felt guilty" and "at least [wanted to give Anderson] something."... [Bonds] considered Anderson a friend whom he paid for his help.... Bonds made his payments to Anderson in lump sums. In 2001, the year he set the Major League Baseball single season home run record, Bonds also provided Anderson, along with other friends and associates, a "gift" of $\$ 20,000$.

Id. at 499. Maybe not so coincidently, Anderson was imprisoned on contempt charges when he refused to testify against Bonds.

131. Id. at 498 . 
before a grand jury that he had never ingested steroids. ${ }^{132}$ As a result of that ruling, the court held that the BALCO log sheets that showed Bonds's name on the samples were also inadmissible hearsay. ${ }^{133}$ The government sought an interlocutory appeal on the admissibility of Anderson's hearsay statements. ${ }^{134}$

The Ninth Circuit's discussion of the residual exception appears much more liberal than that of the Eleventh Circuit in Mazer. ${ }^{135}$ The Bonds court began by observing that Rule 807 "provide[s] judges a 'fair degree of latitude' and 'flexibility' to admit statements that would otherwise be hearsay." 136 Nonetheless, when considering the trustworthiness of Anderson's statements, the court used practical considerations to distinguish those statements from hearsay previously held to be trustworthy under the residual exception. The court first observed that, unlike in other cases, Anderson's statements were not videotaped and under oath, which made them far less trustworthy. ${ }^{137}$ Further, the court noted that, unlike residual-exception cases where statements were admitted because the declarant was truly unavailable, ${ }^{138}$ there were no "exceptional" circumstances that rendered Anderson's statements absolutely necessary. ${ }^{139}$ The court reasoned that the circumstances did not render it admissible under the residual exception "because it involves statements of an unavailable witness like those FRE

\footnotetext{
132. Id. at 500 .

133. Id.

134. Id. at 498 .
}

135. Compare United Techs. Corp. v. Mazer, 556 F.3d 1260, 1278-79 (11th Cir. 2009) (upholding district court's exclusion of statements under Rule 807 after thorough review of the court's findings), with FTC v. Figgie Int'l, Inc., 994 F.2d 595, 608 (9th Cir. 1993) (upholding an admission under Rule 807 as harmless error despite the fact that the district court made no findings of fact to support its judgment).

136. Bonds, 608 F.3d at 501 (quoting United States v. Valdez-Soto, 31 F.3d 1467, 1471 (9th Cir. 1994)). The court also noted that its "sister circuits have also given district courts wide discretion in the application of FRE 807, whether it be to admit or exclude evidence." Id.

137. Id.

138. See, e.g., United States v. Sanchez-Lima, 161 F.3d 545, 547-48 (9th Cir. 1998) (exceptional circumstances found because declarant had since been deported).

139. See Bonds, 608 F.3d at 501. The court also rejected the government's near-miss argument: [W] here a statement "almost fit[s]" into other hearsay exceptions, the circumstance cuts in favor of admissibility under the residual exception. We did not, however, hold the factor was determinative, only that it supported the district court's application of FRE 807 in that case to admit the evidence. In this case, even though this was a "near miss" it was nevertheless a "miss" that may have permitted, but did not alone compel the trial court to admit Anderson's statements under FRE 807.

Id. (citations omitted). The near-miss theory is discussed infra Part III.A.3. 
804 excludes, with limited exceptions here not applicable." ${ }^{140}$ Lastly, the court held that the district court did not err in concluding that the statements were untrustworthy based, in part, on the fact that the BALCO employee admitted he had intentionally mislabeled samples at Anderson's request. ${ }^{141}$ The court concluded that, despite Anderson's close relationship with Bonds, the employee's admission rendered Anderson's statements about the source of the samples untrustworthy. ${ }^{142}$

These cases tend to demonstrate that courts generally take an allencompassing approach to determining whether a statement possesses "circumstantial guarantees of trustworthiness" that are equivalent to the hearsay exceptions in Rules 803 and 804. In examining those circumstances, courts traditionally focus on the facts surrounding the making of the statement, relying on all of the available evidence while making fact-specific, i.e., not categorical, assessments of the statement's trustworthiness. In light of Wright, ${ }^{143}$ courts view corroborating evidence with suspicion, but allow it to be considered as a nondeterminative factor when evaluating the circumstances of trustworthiness. While courts consider different factors when determining trustworthiness, ${ }^{144}$ the basic requirement is that circumstances surrounding the making of a hearsay statement are considered as part of a relatively unbounded inquiry. However, not only must a trial court consider the guarantees of trustworthiness, but those guarantees must also be equivalent to the guarantees of trustworthiness inherent in the Rule 803 and 804 hearsay exceptions. What makes those guarantees of trustworthiness equivalent for Rule 807 purposes is an entirely different debate - a debate surrounding what is commonly known in the courts and legal literature as the "near-miss" theory.

\section{Near Misses}

There is considerable disagreement among courts about whether it is

\footnotetext{
140. Id. at 501-02.

141. Id. at 502 .

142. Id. ("To the extent the government contends that the district court improperly focused on Valente's trustworthiness instead of on the trustworthiness of Anderson's statements, the government misinterprets the district court's opinion.").

143. See supra Part III.A.1 for a discussion of Wright and the Confrontation Clause limitations on the admission of hearsay against a criminal defendant.

144. See supra text accompanying notes $72-75$. The Eleventh Circuit best summarized the myriad approaches taken by federal courts in ascertaining the trustworthiness of hearsay under the residual exception in Rivers v. United States, 777 F.3d 1306, 1315 (11th Cir.), cert. denied, 136 S. Ct. 267 (2015).
} 
appropriate to use the residual exception to admit a hearsay statement that approaches, but fails to fully satisfy, the requirements of an established hearsay exception-i.e., near-miss hearsay. A majority of state and federal courts have accepted the notion that near-miss hearsay may be admitted. ${ }^{145}$ For example, the Michigan Supreme Court has stated that a "great majority of courts have" declined to exclude statements as near-miss hearsay "by interpreting the residual exception to omit as 'specifically covered' only those hearsay statements admissible under a categorical exception. A statement not admissible under the categorical exceptions ... thus could be a candidate for admissibility under the residual exceptions." ${ }^{146}$ The propriety of the admission of near-miss hearsay turns on a truly odd and non-contextual interpretation of the introductory clause of Rule 807: "Under the following circumstances, a hearsay statement is not excluded by the rule against hearsay even if the statement is not specifically covered by a hearsay exception in Rule 803 or $804 . "{ }^{\prime 47}$ That is, the majority of courts that admit near-miss hearsay claim to do so on the ground that Rule 807 permits the admission of otherwise inadmissible hearsay because it is not covered by a categorical exception. As was argued in Residual Exceptions, reliance on this narrow metric utterly flies in the face of the Rule's explicit history and purpose - the relatively rare admission of hearsay of a type that was never contemplated by any of the categorical exceptions. $^{148}$

For example, acceptance of the admission of near-miss evidence has permitted courts to admit bank business records that fail to qualify as records of regularly conducted activity despite their failure to meet the reliability requirements codified in Rule 803(6). No one could plausibly argue that Congress did not contemplate the admissibility of bank records or that bank records which are missing any of the trustworthiness requirements found in Rule 803(6) possess "equivalent guarantees of trustworthiness" to records that fully satisfy Rule 803(6). Indeed, courts that reject the admission of near-miss hearsay argue that "a statement that is 'specifically covered' by one of the enumerated exceptions in

145. See Bocchino \& Sonenshein, supra note 71, at 74 (discussing the "liberal admissibility that most federal appellate courts provide to so-called 'near-miss' residual hearsay").

146. People v. Katt, 662 N.W.2d 12, 20 (Mich. 2003). "[W]e decline to adopt the near-miss theory as part of our method for determining when hearsay statements may be admissible under MRE 803(24)." Id. at 21.

147. FED. R. EVID. 807(a).

148. See Residual Exceptions, supra note 1, at 885-88. 
Rule 803 or 804 is ineligible even to be considered for admission pursuant to the residual exception." ${ }^{149}$ These courts reason that the admission of out-of-court statements that do not satisfy the requirements for admission under an enumerated exception in Rule 803 or 804 is inconsistent with the original vision of the exception-a limited exception that should be reserved for "novel or unanticipated" categories of hearsay not expressly covered by Rule 803 or 804 , but that are equally reliable. ${ }^{150}$

Although some circuits had ruled that grand jury testimony was admissible against a criminal defendant ${ }^{151}$ prior to the seminal Supreme Court Confrontation Clause decision in Crawford v. Washington, it would seem that such cases have now been effectively overruled by Crawford because of the lack of cross examination. ${ }^{152}$ In United States $v$. Dent, the Seventh Circuit reversed a district court's admission of specific grand jury testimony under the residual exception, holding that the testimony did not possess sufficient "circumstantial guarantees of trustworthiness" to be admitted under the Rule. ${ }^{153}$ By reversing the district court's fact-based trustworthiness determination, the court avoided the broader legal question of whether the residual exception ever applies to grand jury testimony. ${ }^{154}$ Judge Easterbrook issued a concurring opinion in which he explained the near-miss admissibility rationale. He argued that the residual exception:

reads more naturally if we understand the introductory clause to mean that evidence of a kind specifically addressed ("covered") by one of the four other subsections must satisfy the conditions laid down for its admission, and that other kinds of evidence not covered (because the

149. DeCoux, supra note 66 , at 102 .

150. See, e.g., State v. Stevens, 490 N.W.2d 753, 760 (Wis. Ct. App. 1992) ("[The residual hearsay exception] is for the novel or unanticipated category of hearsay that does not fall under one of the named categories, but which is as reliable as one of those categories.").

151. Compare United States v. Earles, 113 F.3d 796, 801 (8th Cir. 1997) (holding that grand jury testimony is admissible under the residual exception even without the opportunity for confrontation), with United States v. Torrez-Ortega, 184 F.3d 1128, 1132 (10th Cir. 1999) ("Admission of Valdez's grand jury testimony therefore violates the Confrontation Clause and is improper under Rule 801(d)(1)(A) because Valdez was not subject to cross-examination.").

152. See Crawford v. Washington, 541 U.S. 36, 68-69 (2004) (holding that "testimonial" out-ofcourt statements offered against a criminal defendant are inadmissible unless the declarant is unavailable and the defendant had an opportunity to cross-examine the declarant).

153. United States v. Dent, 984 F.2d 1453, 1463 (7th Cir. 1993), abrogated by Crawford v. Washington, 541 U.S. 36 (2004).

154. Id. at 1465 (Easterbrook, J., concurring) (observing that the majority's opinion "enables the court to avoid the question whether [the residual exception] applies to grand jury testimony in the first place"). 
drafters could not be exhaustive) are admissible if the evidence is approximately as reliable as evidence that would be admissible under the specific subsections. ${ }^{155}$

The following cases - all of which endorse admission of near-miss hearsay-represent the majority view of state and federal courts. In United States v. Clarke, a case concerning the admissibility of prior testimony under the residual exception, the Fourth Circuit admitted nearmiss hearsay. ${ }^{156}$ In Clarke, the out-of-court statement was held inadmissible under Rule 804(b)(1). ${ }^{157}$ The facts of Clarke, as with many residual exception cases, are quite dramatic. Clarke involved Jane Latimer who, after consenting to a search, was arrested with over five hundred grams of crack cocaine in a toolbox that was hidden in the wheel-well of a rental car. ${ }^{158}$ Latimer cooperated with authorities, who allowed her to conduct a staged delivery of the drugs to Michael Clarke at a North Carolina motel. ${ }^{159}$ Michael Clarke was arrested and subsequently indicted for possession with intent to distribute. ${ }^{160} \mathrm{He}$ moved to suppress the drugs. ${ }^{161}$ At the suppression hearing Michael testified that his brother, Christopher Clarke, had purchased the cocaine. ${ }^{162}$ Christopher was then indicted and tried for conspiracy. ${ }^{163}$ At trial, Michael Clarke refused to testify against his brother. ${ }^{164}$

The district court held that by refusing to testify, Michael was legally "unavailable." 165 Despite the clear inadmissibility of the testimony under the prior-testimony exception to the hearsay rule, ${ }^{166}$ the lower court held that, under the residual exception, Michael's testimony from the suppression hearing was admissible at his brother's trial. ${ }^{167}$ Christopher

155. Id. at 1465-66; see also People v. Katt, 662 N.W.2d 12, 18-19 (Mich. 2003) (quoting the Dent concurrence and discussing the near-miss debate).

156. United States v. Clarke, 2 F.3d 81, 84-85 (4th Cir. 1993).

157. Id. at 83 .

158. Id. at $82-83$.

159. Id. at 83 .

160. Id.

161. Id.

162. Id

163. Id.

164. Id

165. Id.

166. See FED. R. EVID. 804(b)(1). The district court held, and the Fourth Circuit ultimately agreed, that Michael's statements were not admissible under the former-testimony exception because they were not offered against a party who "had an opportunity and similar motive to develop the testimony by direct, cross or redirect examination." Clarke, 2 F.3d at 83.

167. Clarke, 2 F.3d at 83. 
Clarke was subsequently convicted, and appealed the evidentiary issue to the Fourth Circuit. ${ }^{168}$

Christopher Clarke argued that the "not specifically covered" language of the residual exception limits the exception "to cases in no way touched by" the exceptions to the hearsay rule that are specifically enumerated in the rules. ${ }^{169}$ Clarke contended that it "would undermine the protections of the evidentiary rules, as well as violate the Sixth Amendment's Confrontation Clause" for the Fourth Circuit to adopt the broad reading of the residual exception raised by the government. ${ }^{170}$ The Fourth Circuit rejected Clarke's argument, holding that such a narrow construction of the residual exception would render it "a nullity." court held that the "specifically covered" language means that "if a statement does not meet all of the requirements for admissibility under one of the prior exceptions, then it is not 'specifically covered" and therefore can be admitted pursuant to the residual exception. ${ }^{172}$

The court reasoned that endorsing the near-miss admissibility interpretation of the residual exception furthers the underlying purpose of the exception-that is, the exception is designed to allow the introduction of reliable evidence that fails to satisfy the requirements of an established exception. ${ }^{173}$ This, of course, is an excessively broad reading of the purpose of the exception in light of its legislative history. ${ }^{174}$ Echoing the Supreme Court's hesitancy to apply the exclusionary rule of the Fourth Amendment expansively, the court harped on the fact that a narrow reading of the residual exception "would deprive the jury of probative evidence relevant to the jury's truth-seeking role," 175 despite the fact that such evidence was never subjected to crossexamination. The court cited many cases allowing the admission of grand jury testimony under the residual exception as additional support for its ruling. ${ }^{176}$ The court expressed concern that an interpretation of the exception that renders evidence that is a "near miss" under a specific exception inadmissible under the residual exception "promises much

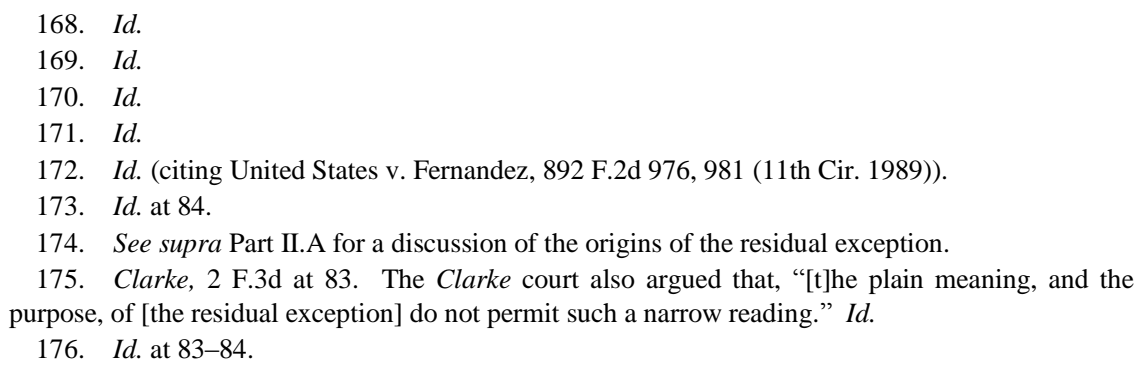


litigation over how close a statement can come to one of the specified exceptions before it is rendered inadmissible." 177 Countless motions over that esoteric question, according to the Clarke court, "would create an odd situation where testimony that was equally trustworthy would be distinguishable based merely on its proximity to a specified exception." ${ }^{\text {178 }}$ The court thus adopted a broad reading of the residual exception, reluctant to set a bright-line rule limiting the scope of the exception to admit evidence that is almost, but not quite, admissible under Rule 803 or 804.

Having rejected the argument that near-miss hearsay should never be admitted pursuant to the residual exception, the Fourth Circuit examined the "equivalent circumstantial guarantees of trustworthiness" of the proffered hearsay. ${ }^{179}$ The court admitted that the suppression hearing testimony did not bear "identical" guarantees of trustworthiness required under nearly missed Rule 804(b)(1), yet the court nonetheless concluded that "they are in their totality equivalent." 180 The court pointed to a variety of facts surrounding the making of Michael Clarke's suppressionhearing testimony that indicated its trustworthiness, including: (1) he was questioned by his own attorney at the hearing; (2) his testimony was given under oath; and (3) he knew that his testimony could not be used against him at trial, decreasing his incentive to lie to avoid conviction. ${ }^{181}$ Accordingly, the court held that Michael Clarke's suppression-hearing testimony incriminating his brother could be introduced under the residual exception, despite not being admissible under the priortestimony hearsay exception. ${ }^{182}$

In United States v. Laster, the Sixth Circuit debated the merits of whether the proper reading of the residual exception permits the introduction of near-miss evidence. ${ }^{183}$ The case involved an appeal by James Laster, who argued that his drug conviction should be overturned

177. Id. at 84 . The court also worried that the inevitable "litigiousness [would be] contrary to the inquiry established by the residual exception, which focuses on whether the statement has "equivalent circumstantial guarantees of trustworthiness."' Id.

178. Id.

179. Id.

180. Id.

181. Id. at $84-85$.

182. Id. at 85. Specifically, the court found that Christopher had "identified no reason for his brother to have falsely implicated him at the suppression hearing, and we can discern none. Under these circumstances, the district court did not err in admitting a statement that had the ring of reliability about it." Id.

183. United States v. Laster, 258 F.3d 525, 529-30 (6th Cir. 2001). 
because it was based on hearsay (purchase orders and other records ${ }^{184}$ involving the purchase of hydriodic acid and various other chemicals used to make methamphetamine) that was improperly admitted under the residual exception by the district court. ${ }^{185} \mathrm{He}$ had attempted to purchase the chemicals in bulk, without authorization, using the company account of his employer, Universal Testing Inc. ${ }^{186}$ On appeal, he argued that the records were improperly admitted "under the business records exception" by the district court. ${ }^{187}$ After examining the facts of the case, the Sixth Circuit panel agreed with Laster that the hearsay evidence failed to meet the requirements for Rule 803(6), but split on the admissibility of the near-miss hearsay pursuant to Rule $807 .{ }^{188}$

Despite the near miss on the business records exception, the court concluded that the purchase orders and related documents were admissible under the residual exception. ${ }^{189}$ The appellate-court majority read the "not specifically covered language" broadly while acknowledging the competing viewpoint on near-miss evidence: "Although some courts have held that if proffered evidence fails to meet the requirements of the Fed. R. Evid. 803 hearsay exception, it cannot qualify for admission under the residual exception, the court declines to adopt this narrow interpretation...." " specifically-covered language simply " "means only that if a statement is admissible under one of the [hearsay] exceptions, [that exception] should be relied upon' instead of the residual exception." 191

Dissenting, Judge Karen Nelson Moore rejected this expansive reading of the residual exception, trenchantly rejecting the panel majority's interpretation of Rule 807 and defending the generic exclusion

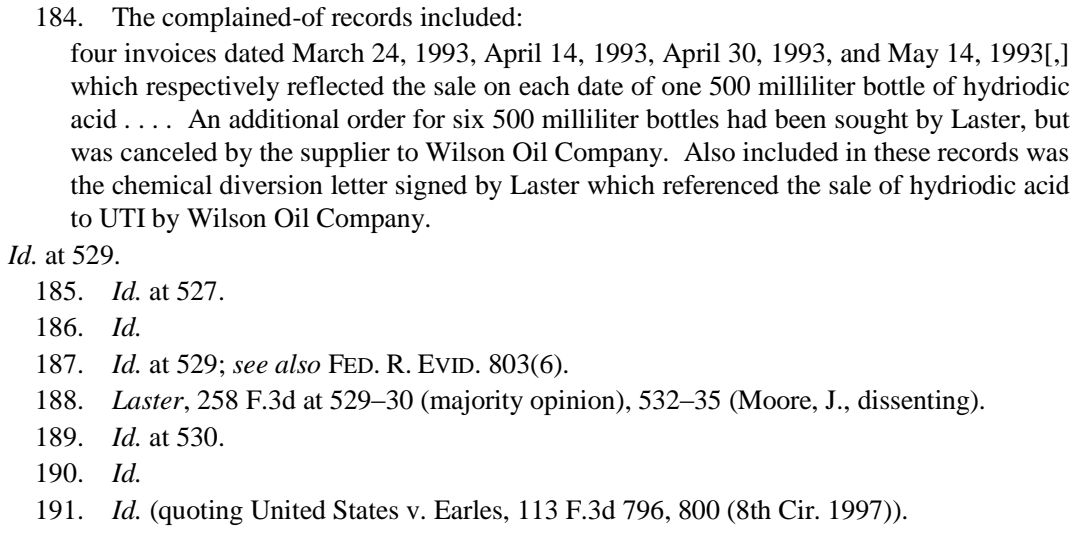


of near-miss hearsay. ${ }^{192}$ Judge Moore argued that by rejecting the nearmiss theory the majority allowed the residual exception to swallow both the rule and all of the other exceptions. ${ }^{193}$ Judge Moore rejected the idea that the words "not specifically covered" meant that Rule 807 applies to statements that are declared inadmissible under Rule 803 or $804 .{ }^{194}$ While acknowledging that her view was the minority view, Judge Moore argued that "[n]ot only is this minority approach consistent with the plain language of the rule, but it is also consistent with the legislative history of the residual exception, and the original Advisory Committee Note to Rule 807's predecessors." 195 Judge Moore quipped that if her minority interpretation is the "near miss" theory of the residual exception, then the majority view should be considered the "close-enough" theory. ${ }^{196}$

Judge Moore further argued that the majority's close-enough approach rendered it irrelevant that the government failed to lay a proper foundation for the admission of the business records because the theory makes it unnecessary to produce a sponsoring witness at trial. ${ }^{197}$ It seems apparent, Judge Moore observed, that business records that lack a sponsoring witness, which was the case in Laster, generally lack "circumstantial guarantees of trustworthiness" under Rule 807. ${ }^{198}$ Judge Moore urged that the Sixth Circuit should not join the other circuits in expanding the residual hearsay exception to cover hearsay situations that were "clearly anticipated by the drafters of the Federal Rules of Evidence." 199 In concluding, she chastised the majority for adopting such a "badly flawed" approach to Rule 807 without even discussing the structure of the rules, the legislative history of the residual exception, or the purpose of the specific hearsay exception at issue (the business records exception). ${ }^{200}$ Despite Judge Moore's persuasive and passionate

192. See id. at 534 (Moore, J., dissenting) ("This plain-language interpretation of the residual exception is sometimes described by its detractors as the 'near-miss theory' of the residual exception ...." (citing United States v. Clarke, 2 F.3d 81, 84 (4th Cir. 1993))); see also Zenith Radio Corp. v. Matsushita Electric Indus. Co., 505 F. Supp. 1190, 1263 (E.D. Pa. 1980) ("The [nearmiss theory] is also supported by a basic principle of statutory construction, which we find equally applicable to the Federal Rules of Evidence: that the specific controls the general.").

193. Laster, 258 F.3d at 535 (Moore, J., dissenting).

194. Id. at 532-33.

195. Id. at 533 (citations omitted).

196. Id. at 534 .

197. Id. ("The majority's holding thus appears to make it unnecessary ever to call a sponsoring witness to establish the admissibility of business records ....").

198. Id. at 535 .

199. Id

200. Id. at 534 . 
dissent, one firmly grounded in both the purpose and the plain language of Rule 807, the Sixth Circuit joined a majority of federal circuit courts by rejecting the near-miss theory in favor of a broad reading of the residual exception.

A majority of state courts have also chosen to admit near-miss hearsay. For example, in People v. Katt, the Supreme Court of Michigan held that the state residual exception ${ }^{201}$ allows for the admission of hearsay statements that narrowly miss one of the categorical exceptions of the state's residual exception. ${ }^{202}$ Katt involved a defendant, Terry Lynn Katt, charged with sexually assaulting a boy and girl under the age of ten while he was living with their mother. ${ }^{203}$ One of the children was interviewed by a social worker, Angela Bowman, who testified during a preliminary hearing. ${ }^{204}$ Bowman testified that the seven-year-old boy detailed Katt's abusive behavior to her, and Bowman related the graphic details of the defendant's abuse to the jury. ${ }^{205}$ The defendant argued, and all of the Michigan courts agreed, that the statement was inadmissible under Michigan's "tender-years" exception to the hearsay rule ${ }^{206}$ because

201. See Mich. R. EVID. 803(24) ("A statement not specifically covered by any of the foregoing exceptions but having equivalent circumstantial guarantees of trustworthiness, if the court determines that (A) the statement is offered as evidence of a material fact, (B) the statement is more probative on the point for which it is offered than any other evidence that the proponent can procure through reasonable efforts, and (C) the general purposes of these rules and the interests of justice will best be served by admission of the statement into evidence. However, a statement may not be admitted under this exception unless the proponent of the statement makes known to the adverse party, sufficiently in advance of the trial or hearing to provide the adverse party with a fair opportunity to prepare to meet it, the proponent's intention to offer the statement and the particulars of it, including the name and address of the declarant."); see also People v. Katt, 662 N.W.2d 12, 17 (Mich. 2003) ("MRE 803(24) is nearly identical to FRE 807.").

202. Katt, 662 N.W.2d at 21; see also Ann K. Triplett, Comment, A Sympathetic Vehicle: Michigan v. Katt and Setting Dangerous Precedent, 37 LOY. L.A. L. REV. 1373, 1373 (2004).

203. Katt, 662 N.W.2d at 14-15.

204. Id. at 15 .

205. Id.

206. The Michigan rule at issue in Katt, categorically titled "Child's Statement About Sexual Act," reads as follows:

A statement describing an incident that included a sexual act performed with or on the declarant by the defendant or an accomplice is admissible to the extent that it corroborates testimony given by the declarant during the same proceeding, provided:

(1) the declarant was under the age of ten when the statement was made;

(2) the statement is shown to have been spontaneous and without indication of manufacture;

(3) either the declarant made the statement immediately after the incident or any delay is excusable as having been caused by fear or other equally effective circumstance; and

(4) the statement is introduced through the testimony of someone other than the declarant. If the declarant made more than one corroborative statement about the incident, only the first is admissible under this rule. 
it was not the first corroborative statement made regarding the incident. $^{207}$ Accordingly, Katt contended that because the tender-years hearsay exception "covers the field" of Bowman's testimony-in that it involved hearsay from a minor of tender years - then the testimony must be inadmissible under the state's residual exception. ${ }^{208}$

Despite the prosecution's concession that the out-of-court statements were inadmissible under the tender-years exception, the trial court held that Bowman's testimony was nonetheless admissible under the residual exception. ${ }^{209}$ The court's holding was based on "several indicia of trustworthiness" in the child's statements to Bowman. ${ }^{210}$ The state intermediate appellate court upheld the trial court, rejecting the defendant's proposal for the state to adopt the position that near-miss evidence is per se inadmissible. ${ }^{211}$ The Michigan Supreme Court was then called on to decide whether to adopt the expansive reading of the residual exception, in which a hearsay statement that is close to, but inadmissible under an established exception, is admissible under the residual exception. ${ }^{212}$

The Michigan Supreme Court began by observing that, were it to adopt the theory supporting the rejection of near-miss hearsay (the nearmiss theory), "a party could never use a residual exception to admit evidence that was inadmissible under, but related to, a categorical exception." 213 In affirming the Michigan Court of Appeals, and joining the federal appellate courts in Laster and Clarke, the Katt court rejected the generic exclusion of near-miss hearsay, stating:

The great majority of courts have rejected the near-miss [exclusion] theory by interpreting the residual exception to omit as "specifically covered" only those hearsay statements admissible under a categorical exception. A statement not admissible under the categorical exceptions

\footnotetext{
MicH. R. Evid. 803A.

207. Katt, 662 N.W.2d at 15, 27.

208. Id. at 15 .

209. Id. at $15-16$.

210. Id. In so holding, the trial court stated:

The Court finds no plan of falsification by [the child] under the circumstances in the record that I have before me, and no- and I do find a lack of motive to fabricate on the child's part. The Court also notes that Miss Bowman testified, and I believe her testimony, she had no preconceived notion that anything of a sexual nature occurred when she walked into the room .... Id. at 16 .

211. Id. at $16-17$.

212. Id. at 14.

213. Id. at 19.
} 
would not be "specifically covered" by those exceptions, and thus could be a candidate for admissibility under the residual exceptions. ${ }^{214}$

The Katt court's interpretation of the residual exception focused on the word "specifically." 15 The court observed that since the word modifies "covered," a "specifically covered" statement must be one that is "conformable to all the requirements of that categorical exception." 216 The court also argued that, "[i]f the rule applied to all evidence not 'covered' by other exceptions," the argument for the exclusion of nearmiss hearsay would be more persuasive. ${ }^{217}$ However, observed the court, 'the rule modifies the term 'covered' with the adjective 'specifically.' Hence, more than simple 'coverage' is required." 218 Accordingly, the court held that a hearsay statement is "specifically covered" under the residual exception only when it is admissible under another specified exception to the hearsay rule. ${ }^{219}$ To put it another way, the Katt court ruled that hearsay qualifies for admission under the residual exception because it fails to meet the requirements for admissible hearsay as prescribed by the legislature for statements of its type.

In so holding, the court stressed that rejection of the near-miss theory is not inconsistent with the purpose of the hearsay rules. ${ }^{220}$ The court reasoned that the requirement that a statement possess equivalent guarantees of trustworthiness to be admitted under the residual exception safeguards against a subversion of the hearsay rule. ${ }^{221}$ Under the Katt approach, "if a near-miss statement is deficient in one or more requirements of a categorical exception, those deficiencies must be made up by alternate indicia of trustworthiness." ${ }^{, 22}$ Assuming the existence of such indicia, under the Michigan Rules of Evidence, the residual

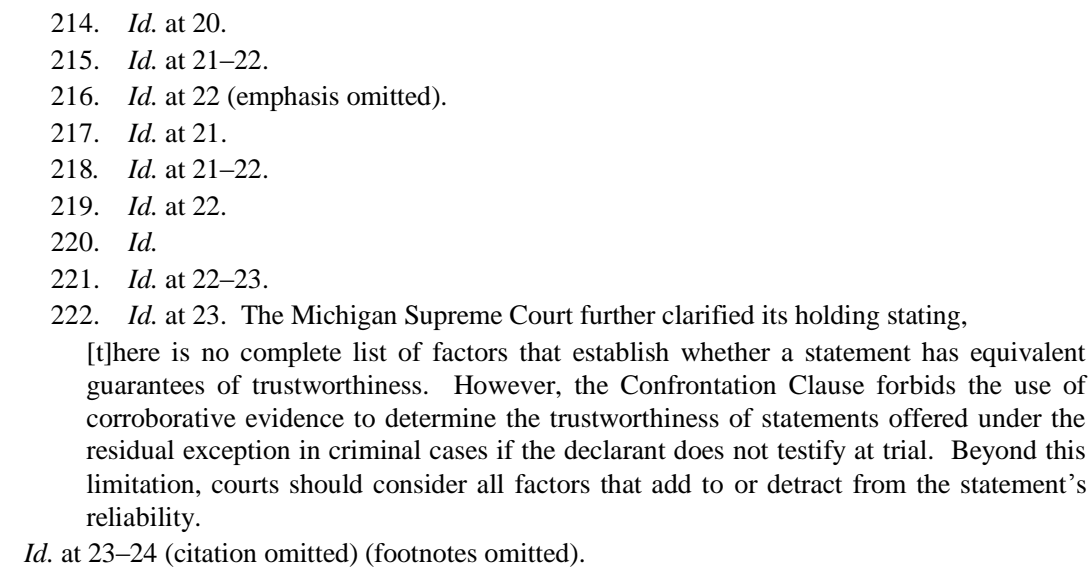
guarantees of trustworthiness. However, the Confrontation Clause forbids the use of corroborative evidence to determine the trustworthiness of statements offered under the residual exception in criminal cases if the declarant does not testify at trial. Beyond this limitation, courts should consider all factors that add to or detract from the statement's reliability.

Id. at 23-24 (citation omitted) (footnotes omitted). 
exception can be used to admit statements that are "similar to, but not admissible under, the categorical hearsay exceptions." 223 The court went on to apply each element of the rule to the statement at issue, and affirmed the state appellate court's ruling that the statement was admissible under the residual exception. ${ }^{224}$

The Katt opinion sparked another passionate dissent, this time from now Chief Justice Robert P. Young Jr. While acknowledging that his support for the near-miss exclusion theory garnered support in only a minority of jurisdictions, Justice Young argued that adopting the theory "best comports with the text of the residual hearsay exception as well as our time-honored prohibition against the admission of hearsay evidence." 225 According to Justice Young, endorsement of the majority's broad reading of the prohibition against hearsay evidence allows for the admission of evidence explicitly held inadmissible under a specific exception to get a second bite at the apple under the all-encompassing residual exception. ${ }^{226}$ Furthermore, Justice Young looked at the exception's drafting history and observed that the intention of the drafters of the residual exception was for it to apply only in "new and presently unanticipated situations."227 Justice Young observed that the majority's approach, which allows for the amorphous "interests of justice" to outweigh the general rule, combined with the extremely deferential standard of review afforded evidentiary determinations, renders the traditional proscription against the use of hearsay evidence "hollow and meaningless." 228 The dissent concluded that the majority's holding in Katt would render the efforts to draw clear lines through the established hearsay exceptions "purposeless," and instead advocated for an approach that "precludes admissibility [under the residual exception] where the evidence does not meet the specific textual requirements of an enumerated hearsay exception." ${ }^{\text {,29 }}$ Nonetheless, in Katt, Michigan

223. Id. at 23 .

224. Id. at 26.

225. Id. (Young, J., dissenting).

226. Id. at 27.

227. Id. at 28 (quoting FED. R. EVID. 803(24) advisory committee's note) (emphasis omitted).

228. Id. at 27-28 ("Against the nearly four-hundred-year-old historical development of our hearsay rules, it is clear that the drafters of the rules did not intend a wholesale trampling of the enumerated hearsay exceptions when the federal residual hearsay exceptions were enacted.").

229. Id. at 28-29; see also id. at 29 ("While the alternative construction proffered by my colleagues in the majority is a principled one, I believe my construction best harmonizes with the actual text of the evidentiary rule as well as our general and historical prohibition against the admission of hearsay evidence. The clear language of the residual hearsay exception precludes admissibility where the evidence does not meet the specific textual requirements of an enumerated 
joined a majority of courts in rejecting the near-miss theory of the residual exception.

Clarke, Laster, and Katt illustrate the prevailing approach to nearmiss hearsay as adopted by state and federal courts. Each court rejects the near-miss interpretation of the residual exception in favor of the broader close-enough approach to the admissibility of residual hearsay. Interestingly, the holdings in all three cases are themselves near misses, in that the courts were divided. As made clear by Judge Moore's and Justice Young's passionate dissents, it is still up for debate as to whether this majority approach can in fact be squared with the history, purpose, and plain language of the residual exception to the hearsay rule. By interpreting the residual exception in such a manner, these courts have exacerbated the current trend of affording judges almost unlimited discretion in admitting hearsay pursuant to the residual exception. This approach is inconsistent with the express intentions of the Rule's drafters as evidenced by the Committee notes, which state the Committee's intent to limit the use of the residual exception to situations where it will "provide for treating new and presently unanticipated situations." 230 By admitting such evidence, it seems that the Rule 807 catch-all exception truly has swallowed all of the other exceptions, and along with it, the traditional ban on the use of hearsay testimony at both civil and criminal trials.

So, given the reality that most courts have chosen to ignore the Rule's clear legislative history and intent and admit near-miss hearsay, what can conscientious courts do to maintain the Rule-mandated obligation to admit only hearsay which bears equivalent guarantees of trustworthiness to that found in the categorical exceptions? The answer lies in an approach suggested in Residual Exceptions more than thirty years ago, an approach that has been adopted by a number of courts. ${ }^{231}$ That approach provides that where a court is forbidden by precedent from per se excluding near-miss hearsay, the court may admit near-miss evidence only where some circumstance in the making of the proffered

hearsay exception.").

230. FED. R. EVID. 803(24) advisory committee's note (repealed 1997), REVISED DRAFT RULES OF EVIDENCE FOR UNITED STATES COURTS AND MAGISTRATES 132 (1971), reprinted in 2 BAILEY \& Trelles, supra note 2; see also United States v. Tome, 61 F.3d 1446, 1452 (10th Cir. 1995) ("Courts must use caution when admitting evidence under Rule 803(24), for an expansive interpretation of the residual exception would threaten to swallow the entirety of the hearsay rule.").

231. See, e.g., Katt, 662 N.W.2d at 23 (holding that, "if a near-miss statement is deficient in one or more requirements of a categorical exception, those deficiencies must be made up by alternate indicia of trustworthiness."). 
out-of-court statement makes up for the missing element(s) of the categorical exception's foundation, thus providing the necessary equivalency of trustworthiness. ${ }^{232}$

\section{B. Probativeness: Probative Value and Reasonable Efforts to Procure Evidence}

Rule 807 requires that for evidence to be introduced under the residual exception it must be "more probative on the point for which it is offered than any other evidence that the proponent can obtain through reasonable efforts."233 Not long after the rule was originally enacted, Residual Exceptions argued that this requirement reads most naturally to require that evidence must be excluded under the residual exception "when other admissible evidence which is at least equally probative" is available. ${ }^{234}$ Most courts read Rule 807(a)(3) to have two functions: (1) it mandates that the hearsay be "more probative" than other evidence on point, and (2) it imposes an obligation on a proponent of the hearsay to endeavor to obtain other evidence that is equally probative before resorting to the residual exception. ${ }^{235}$ This requirement - which traces its origins to the necessity requirement announced in Dallas County-"was designed to limit admission to hearsay of "high probative value and necessity.",236 Shortly after the inception of the Rule, numerous courts chose to find residual hearsay most probative where it "might be useful in helping the jury resolve conflicting evidence."237 As Residual

232. Residual Exceptions, supra note 1, at 888.

233. FED. R. EVID. 807(a)(3); see also Bocchino \& Sonenshein, supra note 71, at 77 ("[E]vidence admitted pursuant to Rule 807 has the advantage of considering and valuing the trustworthiness of the statement, the necessity for a fair determination of the case and the interests of justice in determining its admissibility ....”).

234. Residual Exceptions, supra note 1, at 889. In Zenith Radio Corp. v. Matsushita Electric Industrial Co., then district judge Edward Becker (later Chief Judge of the Third Circuit) read the probativeness requirement narrowly: "[I]t would be a travesty if the plaintiffs were permitted to invoke the residual exceptions when by a calculated litigation strategy they refused to even seek the necessary foundation required by the traditional hearsay exceptions." 505 F. Supp. 1190, 1276 (E.D. Pa. 1980), aff'd in part, rev'd in part sub nom. In re Japanese Elec. Prods. Antitrust Litig., 723 F.2d 238 (3d Cir. 1983), rev'd sub nom. Matsushita Elec. Indus. Co. v. Zenith Radio Corp., 475 U.S. 574 (1986).

235. See Residual Exceptions, supra note 1, at 888.

236. Id.

237. Id. at 890; see also Huff v. White Motor Corp., 609 F.2d 286, 294-95 (7th Cir. 1979) (admitting hearsay where declarant was the only one who knew what happened at the time); United States v. Toney, 599 F.2d 787, 790 (6th Cir. 1979) (admitting hearsay in light of conflicting evidence); United States v. Iaconetti, 406 F. Supp. 554, 559-60 (E.D.N.Y. 1975) (admitting witnesses' hearsay testimony about a conversation of the defendant's because their testimony was 
Exceptions noted, this "tie-breaking" approach that had been adopted by various circuits was inconsistent with the purposes of the exception, unless the court actually determines that the tie-breaker is itself more probative than the conflicting evidence. ${ }^{238}$

It is difficult to generalize a common approach to probativeness utilized by courts because each probativeness analysis varies greatly depending on the details and characteristics of the out-of-court statement being offered, the specific "point" for which the hearsay is being offered to prove, other evidence available to the offering party, and, of course, the facts and circumstances attendant to trial. Courts have announced rules relating to the residual exception that appear to read aspects of the probativeness requirement more broadly than the plain language of Rule 807 suggests. The requirement that an out-of-court statement be "more probative on the point for which it is offered than any other evidence" does not mean that the evidence must be essential; rather, in some jurisdictions it means that the statement must be merely helpful to the fact-finder and not completely superfluous. ${ }^{239}$ Under this view, evidence can be more probative in situations where other probative evidence was already available at trial to prove the same point as the hearsay admitted under the residual exception. On the other hand, some courts have held that the plain language of the residual exception "essentially creates a 'best evidence' requirement." 240 This is the more restrictive view of the

the only testimony that could help clear up a direct conflict between the government's chief witness and the defendant's testimony), aff'd, 540 F.2d 574 (2d Cir. 1976).

238. Residual Exceptions argued that:

[T] he "tie-breaking" view of probativeness is inconsistent with the view of both the Advisory Committee and Congress that the residual exceptions shall be applied sparingly and only in extraordinary situations. After all, virtually all cases which go to trial turn on conflicting versions of the facts. It could nearly always be said that the jury would be helped by the admission of additional evidence. Therefore, if the probativeness requirement for the proffered hearsay is met whenever a clear conflict in the evidence exists, the residual exceptions could be applied routinely and in rather ordinary situations. Indeed, the probativeness requirement would be a virtual dead letter. Residual Exceptions, supra note 1, at 893.

239. See United States v. Howard, 774 F.2d 838, 846 (7th Cir. 1985) ("[T]he Rule 'does not require that hearsay evidence be essential in order that it be admissible,' but instead '[i]t is enough that it is the most probative evidence reasonably available on a material issue in the case." (quoting United States v. Boulahanis, 677 F.2d 586, 589 (7th Cir. 1982))).

240. See Larez v. City of L.A., 946 F.2d 630, 644 (9th Cir. 1991) ("The statements' admission, therefore, was erroneous because the newspaper quotations were not the best available evidence of what Gates said; testimony from the reporters themselves would have been better. The Larezes knew as much for they had the reporters subpoenaed and apparently ready to testify. We cannot fault defense counsel for he specifically requested an opportunity to cross-examine the reporters before the evidence was admitted."). 
probativeness requirement. The following cases are representative of the varying interpretations of Rule 807 in the federal courts. Of particular note, and largely unaddressed by residual-exception scholarship, these courts suggest that litigants can strategically prevent an adversary from introducing evidence under the residual exception by utilizing judicial precedent interpreting the meaning of more probative or by pointing out the lack of effort by the proponent to develop more probative, admissible evidence.

\section{The Basics: United States v. Howard}

In 1985, the Seventh Circuit addressed the meaning of the probativeness requirement in United States v. Howard. ${ }^{241}$ In 1982, Edward Howard and Thomas Cusack, Democratic precinct captains in the city of Chicago, were indicted in a thirty-three-count indictment with charges ranging from voter fraud to mail fraud. ${ }^{242}$ Howard and Cusack, along with other local politicians and a local judge, had concocted a conspiracy to rig the ballot for the forty-fourth precinct of Chicago. ${ }^{243}$ The scheme involved the voter registration process and the voting process:

Several persons, including the defendant Cusack, falsely registered to vote by claiming to reside at addresses within the precinct when they actually resided elsewhere. The actual residents at these addresses were asked to place name-tags on their doors that bore the names of the non-resident registrants. The defendants, and several others acting under their direction, also participated in a canvass of the precinct during September and October 1982. Although the canvass disclosed that a number of persons who were registered to vote in the precinct had died, moved away, or for some other reason had become ineligible to vote, these persons were not struck from the list of eligible voters.

241. Howard, 774 F.2d at 845-46.

242. Id. at 840 . The charged offenses included:

[1] conspiracy in violation of 18 U.S.C. $\S \S 241$ and 371 (1982), voting more than once in an election held in part for the purpose of electing a member of the United States House of Representatives in violation of 42 U.S.C. § 1973i(e) (1982), [2] giving false information to establish eligibility to vote in such an election in violation of 42 U.S.C. § 1973i(c) (1982), [3] committing mail fraud in connection with the mailing of absentee ballots in violation of 18 U.S.C. $§ 1341$ (1982), and [4] aiding and abetting others in the Id. commission of these offenses in violation of 18 U.S.C. $§ 2$ (1982).

243. Id. ("In addition to the defendants, the participants in the conspiracy included Darryl Cunningham, a Democratic precinct worker, and Charlotte Watson, a Republican election judge, both of whom were named as unindicted co-conspirators in the indictment against the defendants."). 
Finally, on election day the defendants, either personally or by acting through others, caused numerous false ballots to be cast for the straight Democratic ticket. ${ }^{244}$

Both were convicted after a ten-day jury trial. ${ }^{245}$ The co-defendants challenged their convictions, alleging that certain hearsay statements made by William Espina were erroneously admitted at trial under the residual exception. ${ }^{246}$ Espina was the true resident at one of the addresses used by Howard to falsely register ineligible voters. ${ }^{247}$ Espina was unavailable to testify at trial, as he had died in the interim. ${ }^{248}$ Prior to his passing, Espina was interviewed by an investigator hired by Howard's attorney. ${ }^{249}$ The transcript of that interview was read to the jury at trial over Howard's objections. ${ }^{250}$ The testimony tended to confirm that Howard gave Espina a specific handwritten nametag to hang on his door, which allowed the jury to infer that Howard was pivotal in the conspiracy.

The Seventh Circuit held that, in light of the substantial discretion vested in district courts to admit residual hearsay, the trial court did not err in admitting Espina's out-of-court statement. ${ }^{251}$ After examining the trustworthiness and materiality of the statement, the court turned to probativeness. Howard argued that the interview with Espina was not the most probative evidence available because the government could have obtained evidence "by examining the name-tag itself for Howard's

244. Id. ("The evidence introduced at the defendants' ten-day trial ... revealed a carefullyorchestrated scheme by the defendants to cast false ballots for the straight Democratic ticket in the November election.").

245. Id

246. Id. at 845. Howard was decided under Rule 804(5), before the two residual exceptions for unavailable and available declarants merged under Rule 807. See id.

247. $I d$.

248. Id

249. Id.

250. Id. More specifically:

An F.B.I. agent testified at trial that when he interviewed Espina at his residence on February 9, 1983, he discovered a tag bearing the name "Sufranski" on Espina's door. Espina volunteered to the agent that Howard had put the tag on his door. The agent removed the tag at Espina's request, and it was introduced at trial. On June 1, 1983, an investigator for Howard's trial counsel interviewed Espina at his residence, and had the interview transcribed by a court reporter. The transcript of the interview, which was read to the jury, revealed Espina reaffirming that Howard had placed the Sufranski name-tag on his door.

Id.

251. Id. at 846 . 
fingerprints or handwriting." 252 The circuit court referred to this argument as mere speculation and concluded that Espina's statements were correctly admitted at trial as the most probative evidence available. $^{253}$

In so holding, the court affirmatively stated that "the Rule 'does not require that hearsay evidence be essential in order that it be admissible,' but instead 'it is enough that it is the most probative evidence reasonably available on a material issue in the case." 254 The court reasoned that Espina's evidence was most probative due to his clear unavailability and the speculative nature of Howard's claim that the government should have gone out and discovered "more probative evidence" that may or may not have existed. ${ }^{255}$ As such, it did not matter whether the government could have sought and obtained other evidence that would have allowed the jury to conclude that Howard placed the sign on the door; what mattered was that Espina's statements were "the only available direct proof" that Howard placed the sign on the door. ${ }^{256}$ The court accordingly concluded that the district court did not abuse its discretion in admitting the statements under the residual exception. ${ }^{257}$

While the Seventh Circuit's holding was both well reasoned and rational, other courts have placed more of a burden on the party seeking to introduce residual hearsay when proving it took reasonable efforts to locate other admissible evidence. Howard begs the following question: When a party argues evidence is inadmissible under Rule 807 because other "more probative evidence could have been obtained through reasonable means," what is "reasonable"? This question lends itself to a case-by-case analysis. It is worth remembering that in Dallas County, the Fifth Circuit found the newspaper account to be the most probative available evidence because of the likelihood that no eyewitnesses would be available some fifty years after the fire. ${ }^{258}$

\section{The Circumstantial-Direct Proof Dichotomy}

When it comes to the determination of the meaning of more

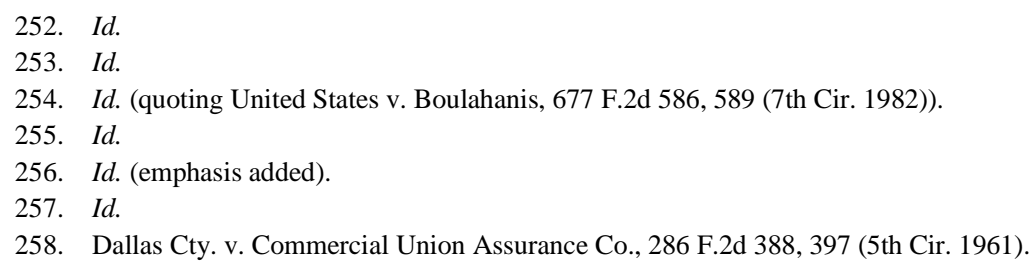


probative evidence for purposes of Rule 807, Howard appears to recognize a hierarchical distinction between direct and circumstantial evidence. Six years before Howard, the Seventh Circuit decided Huff $v$. White Motor Corp. ${ }^{259}$ one of the most widely cited residual-exception cases. ${ }^{260}$ In Huff, Helen Huff filed a wrongful death action against White Motor Corp. for the death of her husband, Jessee Huff, on the theory that the fuel tank of Huff's truck-tractor was defectively designed. ${ }^{261}$ While driving his tractor on the highway, the cab of tractor caught fire, which led to severe, and ultimately fatal, burns. ${ }^{262}$ Two days after the accident, while in the hospital, Huff gave an account of what happened leading up to the fire and ensuing crash. ${ }^{263}$ The district court admitted the statement under the residual exception, and the jury returned a $\$ 700,000$ verdict. $^{264}$

On appeal, the Seventh Circuit required the admission of Huff's statement under the residual exception. ${ }^{265}$ In addressing the probativeness requirement, the court concluded that Huff's testimony was the most probative evidence available because the only other relevant evidence about the events leading up to the fire-particularly, whether the fire in the cab preceded the crash-was expert opinion and "circumstantial testimony" from another witness about "what he saw when he arrived at the scene after the crash." 266 Because "Huff was in the cab immediately before the crash and knew whether there was a fire in the cab at that time," the court observed, "[u]nless the hearsay is admitted, there will be no direct evidence on that question."267 Accordingly, the court found that the direct hearsay evidence was undoubtedly more probative than the live, in-court testimony of other witnesses who had only circumstantial knowledge of the underlying events. ${ }^{268}$

Other courts have followed suit in addressing the distinction between circumstantial and direct proof for probativeness purposes. The Ninth Circuit, for example, has suggested that when an out-of-court statement

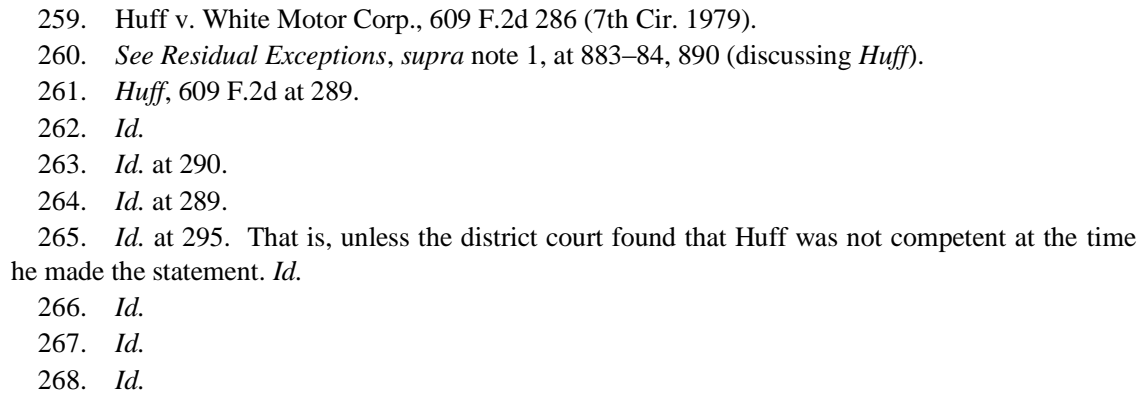


provides direct proof of a disputed fact-as opposed to circumstantial proof - it almost always constitutes the most probative evidence under Rule $807 .^{269}$

In 2001, Reed Slatkin was convicted of operating a Ponzi scheme. ${ }^{270}$ "Slatkin's Ponzi scheme involved over \$593 million and approximately 800 investors, and resulted in losses exceeding \$240 million." 271 He pled guilty and was subsequently sentenced to fourteen years in prison. ${ }^{272}$ In In re Slatkin, the trustee of the bankruptcy estate of Reed Slatkin initiated adversary proceedings for recovery and avoidance against numerous Slatkin investors who were paid out of the scheme. ${ }^{273}$ Reed's plea agreement was admitted under the residual exception at the recovery proceedings. ${ }^{274}$ The Ninth Circuit affirmed, holding that "Slatkin's admissions in the plea agreement that he operated a Ponzi scheme, and that he did so with the actual intent to defraud, are more probative on these issues than any other evidence the Trustee could procure."275 The court reasoned that because "direct proof of fraudulent intent is rarely available," the introduction of the plea agreement under the residual exception would obviate the need for the Trustee to prove the element with circumstantial evidence. ${ }^{276}$ Accordingly, the court upheld the admission under the residual exception, holding that the plea agreement was the most probative evidence available on the issue of fraudulent intent, regardless of any reasonable efforts the trustee could have taken to procure evidence tending to prove such intent. ${ }^{277}$

This distinction between direct and circumstantial proof may leave litigants with a confounding strategic choice when faced with an adversary who is seeking to introduce certain harmful hearsay statements

269. See Santa Barbara Capital Mgmt. v. Neilson (In re Slatkin), 525 F.3d 805, 812 (9th Cir. 2008) ("Slatkin's admissions in the plea agreement that he operated a Ponzi scheme, and that he did so with the actual intent to defraud, are more probative on these issues than any other evidence the Trustee could procure.”).

270. Id. at 809. When discussing Slatkin's actions, the court noted that under the scheme, Slatkin "paid investors purported profits primarily using funds raised from other investors." Id.

271. Id.

272. Id.

273. Id. "[T] he Trustee sought to avoid as fraudulent any transfer made by Slatkin to an investor to the extent that such transfer exceeded the amount the investor had given Slatkin, i.e., the amount of the investor's purported profit on their investment." Id.

274. Id. at 810-811; see also id. at 811-12 (affirming the bankruptcy court's admission of the plea agreement, though noting that the court had not indicated which exception it was admitted under).

275. Id. at 812 .

276. Id

277. Id 
under the residual exception. In that situation, a party could theoretically stipulate to "the point for which [the hearsay] is offered," rendering the hearsay less probative than the stipulation. ${ }^{278}$ This maneuver would keep evidence from the jury that might otherwise allow a jury to draw inferences from the evidence beyond the specific point for which it is offered. This strategy may arise more frequently if courts adopt the First Circuit's confusing approach in United States v. Sposito, in which the residual hearsay does not have to be offered to prove a material fact. ${ }^{279}$

For instance, imagine that the government seeks to introduce a diary entry written by the victim under the residual exception at a murder trial, arguing that it is the most probative evidence available because the victim cannot testify. The prosecution plans to have the victim's diary entry read to the jury in a dramatic fashion. Suppose further that the diary contained facts and circumstances surrounding the day of the murder and the defendant's relationship with the victim, thus tending to suggest that they had a recent falling out. The defense attorney is concerned that the dramatic reading of the diary will humanize the victim at the expense of the defendant; yet the attorney cannot call the defendant to testify. In that scenario, it may well be in the best interests of the defendant to stipulate to the facts contained in the diary. Such a strategy would effectively thwart the government's ability to offer circumstantial (and more damning) evidence - that is, the diary - to prove the point under the residual exception. This type of strategizing may be encouraged in light of the direct versus circumstantial dichotomy currently embraced by the Seventh Circuit in Howard and the Ninth Circuit in In re Slaktin.

3. Reasonable Efforts to Procure More Probative Evidence and the Relevance of Witness Credibility

In situations not involving direct evidence, courts have placed a burden on the proponent of residual hearsay to come forward with proof that it went through reasonable efforts to locate more probative evidence. While this Article has examined many cases in which the district court admitted evidence under the residual exception, there are numerous cases in which courts have found that a failure to prove due diligence can render the residual exception unavailable as a means of introducing

278. FED. R. EVID. 804(b)(5)(B).

279. United States v. Sposito, 106 F.3d 1042, 1047 (1st Cir. 1997). See infra notes 303-23 and accompanying text for a discussion of Sposito. 
hearsay. ${ }^{280}$ In United States $v$. Welsh, the government appealed from a district court order excluding certain hearsay statements for failing to satisfy the probativeness requirement of the residual exception. ${ }^{281}$ In Welsh, a grand jury issued three different indictments for crimes allegedly committed by six defendants - crimes including "transporting stolen motor oil and a semi-trailer," "theft of the oil from interstate shipment," and "transporting in interstate commerce a stolen John Deere bulldozer." 282

The government notified the defendants of its intention to introduce three written statements given to the FBI by Roger E. Massie as part of a plea bargain at trial. ${ }^{283}$ Massie was a truck driver involved in the interstate conspiracy, and the agreement detailed each defendant's involvement in the conspiracy. ${ }^{284}$ Massie committed suicide shortly after he signed the plea agreement. ${ }^{285}$ The government sought to introduce the written statements at trial to establish the facts and circumstances surrounding the interstate conspiracy. ${ }^{286}$ At trial, however, James Casey - a government informant who was also a truck driver in the conspiracy-was available to testify to all of the facts contained in Massie's statements. ${ }^{287}$ The government did not dispute that Casey would be available at trial to testify to the facts contained in Massie's plea agreement. ${ }^{288}$ The district court accordingly held that the statements were inadmissible under the residual exception because they were not more probative than Casey's potential testimony. ${ }^{289}$ The government appealed to the Fourth Circuit.

\footnotetext{
280. See, e.g., United Techs. Corp. v. Mazer, 556 F.3d 1260, 1279 (11th Cir. 2009) ("UTC could have taken reasonable steps to obtain admissible testimony directly from Mazer prior to the district court's ruling on APM's motion to dismiss, but it failed to do so. As such, Rule 807 cannot salvage the admissibility of Mazer's statements ...."); Eisenstadt v. Centel Corp., 113 F.3d 738, 743 (7th Cir. 1997) (holding that evidence was inadmissible under the residual exception because "plaintiffs could easily have obtained the reporter's affidavit even if it was for some reason infeasible to depose him"); Am. Civil Liberties Union of Nev. v. City of Las Vegas, 13 F. Supp. 2d 1064, 1070 (D. Nev. 1998) ("[S]tatements quoted in newspaper articles fail to satisfy the best evidence requirement of subsection (B) because testimony from reporters or editors themselves regarding what Mayor Jones and Mr. Paris said or wrote would have been better evidence.”).

281. United States v. Welsh, 774 F.2d 670, 673 (4th Cir. 1985).

282. Id. at 671

283. Id.

284. Id.

285. Id.

286. Id. at 671-72.

287. Id. at 671 .

288. Id. at 671-72.

289. Id. at 671 .
} 
On appeal, the government conceded that Casey's potential testimony and Massie's written statements would be offered to prove the same set of facts. ${ }^{290}$ The government nonetheless argued that, under the residual exception, Massie's statements were more probative than Casey's testimony because Casey lacked credibility before a jury. ${ }^{291}$ Casey had a history of lying to federal officers and committing perjury, which the defense would surely use to impeach Casey on crossexamination. $^{292}$ The government introduced evidence that tended to show that Casey was not a trustworthy witness; he testified as a principal government witness at two separate criminal trials, and neither trial resulted in a guilty verdict. ${ }^{293}$ The court even acknowledged that "there [was] some support for the government's argument that Casey [was] not a very credible witness." ${ }^{294}$ Despite these arguments, and the availability of Massie's unimpeachable statements to further the likelihood of conviction, the Fourth Circuit upheld the district court's refusal to admit the evidence under the residual exception. ${ }^{295}$

The Fourth Circuit reasoned that the government's logic was flawed because credibility is not synonymous with probativeness. ${ }^{296}$ After defining both credibility and probativeness, ${ }^{297}$ the court announced a bright-line rule regarding the import of a potential witness's credibility under Rule 807: "[T] he credibility of a witness has nothing to do with whether or not his testimony is probative with respect to the fact which it seeks to prove." 298 Despite the fact that Massie's statement was clearly more credible than other evidence on the same point, the court held that

290. Id. at $671-72$.

291. Id. at 672 ("[T] he government argues that Massie's statements are more probative than Casey's testimony would be because Casey would not be a believable witness.").

292. Id.

293. Id. Interestingly, the government argued that "those acquittals resulted primarily because the juries would not convict on the basis of Casey's testimony." Id.

294. Id.

295. Id. at 673 ("Casey's proposed testimony is just as probative as Massie's statement, although Casey may be a less credible man than was Massie. We are thus of opinion the district court was correct in its holding ....").

296. Id. at 672 ("We think the government's position is not sound for it confuses the terms probative and credible.").

297. Id. The Fourth Circuit explained that:

The probative value of evidence is its "tendency ... to establish the proposition that it is offered to prove." Evidence has probative value if it tends to prove the issue in dispute.

Credibility on the other hand goes to "the quality or power of inspiring belief." "A credible witness is one who, being competent to give evidence, is worthy of belief."

Id. (citations omitted).

298. Id. 
Massie's written statements were not more probative on the facts surrounding the conspiracy than Casey's testimony - as required for admission under the residual exception. ${ }^{299}$ Welsh thus stands for the proposition that credibility is not a component of either relevance or probativeness for residual exception purposes.

The majority's credibility-probativeness distinction elicited a short dissent from Judge Kenneth Keller Hall. Judge Hall argued that Casey's proposed testimony was in no way equally probative to Massie's written statements. ${ }^{300}$ He argued that Casey's testimony was "so unworthy of belief as to lack any probative value whatsoever." have reversed the district court for abuse of discretion in refusing to admit the evidence under the residual exception. ${ }^{302}$

Welsh suggests, then, that if a party has only hearsay, or a less than credible witness available to testify to disputed facts, the witness' testimony constitutes more probative evidence regardless of credibility.

\section{The Relationship Between Materiality and Probativeness}

The First Circuit had the opportunity to discuss the relationship between the materiality and probativeness requirements in 1997. In United States v. Sposito, defendant Michael Sposito challenged the district court's admission of Louis Padova's testimony under the residual exception at his trial for illegal gambling. ${ }^{303}$ Padova had testified under a compulsion and immunity order at the trial of another man, Arthur Marder, who had been charged with illegal gambling. ${ }^{304}$ At Marder's trial, Padova testified that Marder had paid off local politicians to protect his illegal gambling enterprise. ${ }^{305}$ According to Padova, Sposito was the middleman through whom these payments were made. ${ }^{306}$ Padova refused, however, to testify at Sposito's trial and was held in contempt. ${ }^{307}$ The government sought to admit Padova's prior testimony from Marder's trial in light of Padova's unavailability, and the district court

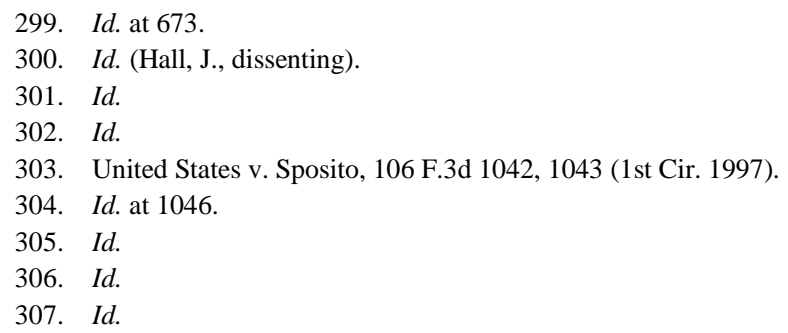


admitted the testimony under the residual exception. ${ }^{308}$ In articulating the point that Padova's testimony was offered to prove, the district court explained: "the testimony relates to a material fact whether Arthur Marder was indeed paying off politicians to obtain protection for his ... business .... If that fact is proven, it increases the likelihood that he was paying off those politicians through Mr. Sposito." ${ }^{09}$ Sposito appealed the ruling that Padova's testimony was the most probative evidence that the government could procure on that point. ${ }^{310}$

The First Circuit took issue with the defendant's assumption that the rule requires residual hearsay to be more probative as it relates to a material fact. ${ }^{311}$ Looking to the plain language of the rule to examine the relationship between the probativeness and materiality requirements, the court observed that, under the residual exception, the statement must only "be more probative "on the point for which it is offered"; nothing in the language requires that point to be one of material fact. ${ }^{312}$ The court supported such a reading by considering the intent of the drafters of the residual exception. ${ }^{313}$ The drafters of the Federal Rules, the court noted, could have easily added the words "of material fact" after "on the point," but refused to do so, opting for a broader conception of what constitutes more probative hearsay. ${ }^{314}$ The court thus held that the rule "does not require that the issue on which the statement is most probative be a material fact; it requires only that it be probative on the point 'for which it is offered.", 315

The court then undertook an in-depth exploration of the Dallas County decision - the inspiration for the residual exception. ${ }^{316}$ The court reasoned that under an alternative construction of the probativeness requirement, the newspaper article in Dallas County addressing the lightening strike on the Dallas County clock tower would not have been admissible. ${ }^{317}$ The court offered the following reasoning, which reads

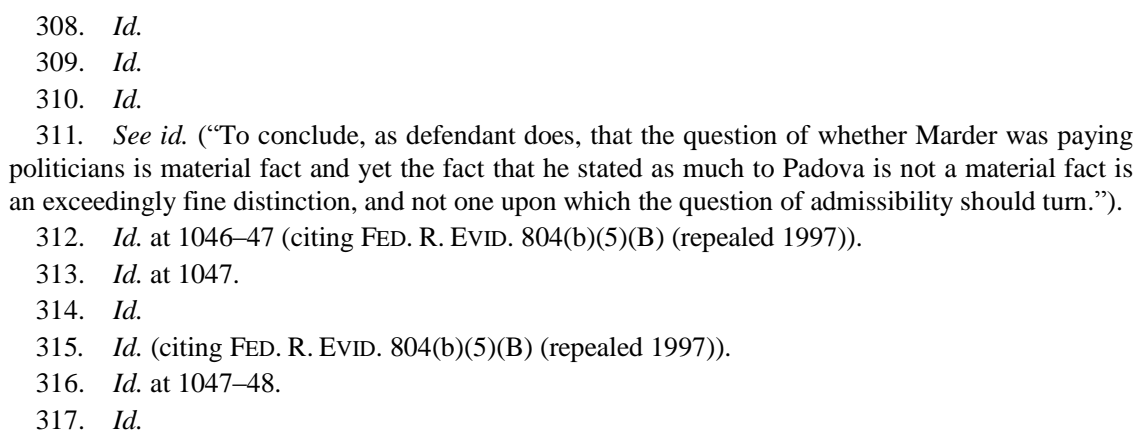


like an LSAT logic game:

The newspaper article was introduced as evidence of the material fact that the charred timbers were the result of a fire that took place more than fifty years prior to the case. The newspaper story did not, however, go directly to the question of why the charred timbers were in the tower, it only went to the fact that there had been a fire in 1901 . The story was not more probative on the point of why the timbers were charred than any other evidence. It was, however, more probative than any other evidence that the insurers could provide on the question of whether there had been a fire. ${ }^{318}$

The court reasoned that, because the drafters of the residual exception were inspired by Dallas County and the newspaper was not more probative as to a material fact, the drafters intended the probativeness inquiry to be separate and distinct. ${ }^{319}$

While Sposito accurately states the influence Dallas County had on the creation of the residual exception, it does not account for the fact that in drafting the residual exception the drafters may have intended to impose more stringent requirements than those imposed by Judge Wisdom in deciding to admit the fifty year-old newspaper article in Dallas County. As Residual Exceptions demonstrated through an indepth examination of the legislative history of the federal rules, ${ }^{320}$ the exception was intended to be more restrictive than the Dallas County approach. ${ }^{321}$ Yet, the First Circuit read the exception as a mere codification of Dallas County. ${ }^{322}$ This approach demonstrates that (as was the case in 1982 when Residual Exceptions was published) courts at times read the residual exception in an exceedingly broad manner, which furthers the trend of unbounded judicial discretion to admit residual hearsay.

Furthermore, the First Circuit's questionable interpretation of the residual exception greatly increases the likelihood that residual hearsay will be admissible. Proponents of such hearsay can just narrowly define "the point for which it is offered" to evidence that goes to a seemingly

\footnotetext{
318. Id.

319. Id

320. See Residual Exceptions, supra note 1, 871-75 (detailing numerous amendments to the residual exception). For an overview of the history of the residual exception, see supra Part II.A.

321. Id. at 871-76; see also id. at 875 ("Legislative history thus shows that Congress intended to balance the need for growth in the law of hearsay with the need for certainty and regularity in the standards for the admission of hearsay. Congress sought to impose guidelines; it did not permit unbounded judicial discretion.").

322. Sposito, 106 F.3d at 1048
} 
similar point. With that said, the court's probativeness-materiality distinction may in fact be a distinction without a difference. As noted by Professor Sonenshein, given the redundant nature of the materiality requirement, and the general requirement that all evidence be material under the rules, it is unclear what, if any, practical effect this attempt to keep probativeness and materiality distinct will have on the admissibility of evidence under Rule $807 .^{323}$

In sum, the propriety of the residual exception often turns on the probativeness requirement. When examining probativeness, numerous factors are at play, thereby making the probativeness inquiry as factbound as judicial attempts to discern trustworthiness. Ultimately, however, when litigants are faced with an adversary seeking to admit residual hearsay, they would be well served to examine the precedent interpreting probativeness with an eye toward using case law strategically to render the hearsay inadmissible. Such a strategy would examine the relationship between materiality and probativess, other efforts the adversary could have or should have taken to procure more probative evidence, and whether it is worth submitting evidence on the same point as circumstantial hearsay to render the hearsay less probative. Therefore, when considering the admissibility of residual hearsay that is potentially harmful to their case, litigants should examine the probativeness requirement closely.

\section{Pretrial Notice: Procedural Safeguard or Discarded Requirement?}

In addition to the four substantive requirements for admission under the residual exception, there is a procedural fairness requirement: the obligation to provide pretrial notice of the intention to offer residual hearsay. As originally adopted in Rules 803(24) and 804(b)(5), the residual exception required notice to be provided "sufficiently in advance of the trial or hearing to provide the adverse party with a fair opportunity to prepare to meet it." ${ }^{24}$ The advisory committee subsequently combined the rules in Rule 807 and made stylistic changes. Rule 807(b) now provides that hearsay is admissible "only if, before the trial or hearing, the proponent gives an adverse party reasonable notice of the intent to offer the statement and its particulars, including the declarant's

323. See supra notes $66-67$ and accompanying text.

324. FED. R. Evid. 803(24), 804(b)(5) (repealed 1997), Federal RulES OF EvidENCE 18-19 (1975), reprinted in 4 BAILEY \& TRELLES, supra note 2. 
name and address, so that the party has a fair opportunity to meet it." 325 The committee made clear, however, that the amendments to the rules were not intended to change the well-established meaning of the residual exception. ${ }^{326}$ The new version includes more specifics, including the particularity requirement and that the declarant's information be made available to an adverse party. ${ }^{327}$ Under both the old version of the rule and the new, the residual exception "seems to provide little flexibility regarding whether notice must be given in advance of trial." 328

Despite that the rule appears to leave little room for judicial whimsy, since its inception, the requirement has not been read as strictly as the plain language suggests. ${ }^{329}$ In 1982, Residual Exceptions demonstrated that "[t]he United States Courts of Appeals are sharply divided between the two views respecting the matter of notice," and have adopted two disparate approaches: the flexible view and the strict view. ${ }^{330}$ The article supported the flexible approach to pretrial notice under the residual exception as a matter of policy, arguing that " $[\mathrm{t}]$ he flexible view satisfies the purpose of the notice requirements, which is to provide adequate time for the opponent to prepare, placing the opponent in no worse position than he would have faced had pretrial notice been given." 331 At the same time, the author noted one not-so-small problem with the flexible approach - that is, the language of the rules "unequivocally require[s] pretrial notice." ${ }^{, 32} \mathrm{He}$ accordingly concluded his article by arguing, "Congress should amend the residual exception rules to conform to the flexible view of notice and rescue the courts that have adopted it from

325. FED. R. EVID. 807(b).

326. The advisory committee made clear in 1997 when the rules were combined that "[n]o change in meaning [was] intended." FED. R. EVID. 807 advisory committee's note to 1997 amendments. In 2011, when the rules were restyled, the committee again stated that "[t]here [was] no intent to change any result in any ruling on evidence admissibility." FED. R. EvID. 807 advisory committee's note to 2011 amendments; see also Bohler-Uddeholm Am., Inc. v. Ellwood Grp., Inc., 247 F.3d 79, 112 n.17 (3d Cir. 2001) ("Bailey addressed the old residual hearsay exceptions contained in Rules 803(24) and 804(b)(5), but because Rule 807 is simply the combination of these rules, Bailey's holding applies to the current Rule 807 as well. The same is true of other pre-1997 cases on the residual hearsay exceptions that are cited in this Section.").

327. See FED. R. EVID. 807(b).

328. Residual Exceptions, supra note 1, at 901.

329. Compare United States v. Bailey, 581 F.2d 341, 348 (3d Cir. 1978) (adopting the flexible approach to pretrial notice), and United States v. Leslie, 542 F.2d 285, 291 (5th Cir. 1976) (similar flexible approach), with United States v. Ruffin, 575 F.2d 346, 358 (2d Cir. 1978) (adopting the strict approach to pretrial notice).

330. Residual Exceptions, supra note 1, at 904.

331. Id

332. Id. 
decisions which are unquestionably correct as a matter of policy, but erroneous as a matter of law." ${ }^{333}$ More than thirty years and two amendments to the residual exception later, Congress has yet to take him up on that all-to-obvious suggestion that would harmonize the text of the rule with its underlying purpose and much judicial practice.

The circuit courts are also split on the situations in which hearsay can be admitted under the residual exception in the absence of timely pretrial notice. In United States v. Panzardi-Lesperi, the First Circuit explained the conflict between the intent of the residual exception and the seemingly clear textual requirement that a proponent provide pretrial notice. ${ }^{334}$ There, Santiago Panzardi-Lespier appealed his conviction and nineteen-year sentence for his involvement in a drug conspiracy. ${ }^{335}$ Specifically, he challenged the admissibility of grand jury testimony of a confidential informant who was murdered before trial, which was introduced at trial pursuant to the residual exception. ${ }^{336}$ The prosecution did not notify Panzardi-Lespier of its intent to introduce the grand jury testimony under the residual exception until the third day of trial. ${ }^{337}$

On appeal, Panzardi-Lespier argued that the notice he received was inadequate and untimely, and he urged the court to adopt the strict interpretation of the pretrial notice requirement. ${ }^{338}$ The First Circuit therefore was tasked with determining whether to adopt the strict approach, which had been adopted by the Second Circuit, ${ }^{339}$ or the flexible approach, which had been adopted by various other circuits including the Third, Eleventh, and Eighth Circuits. ${ }^{340}$ First Circuit precedent had endorsed the flexible approach in civil cases, but cautioned that such an approach might not be appropriate in the criminal context. $^{341}$ The court affirmatively stated that the appeal required that it "examine the issue in the context of a criminal case." 342

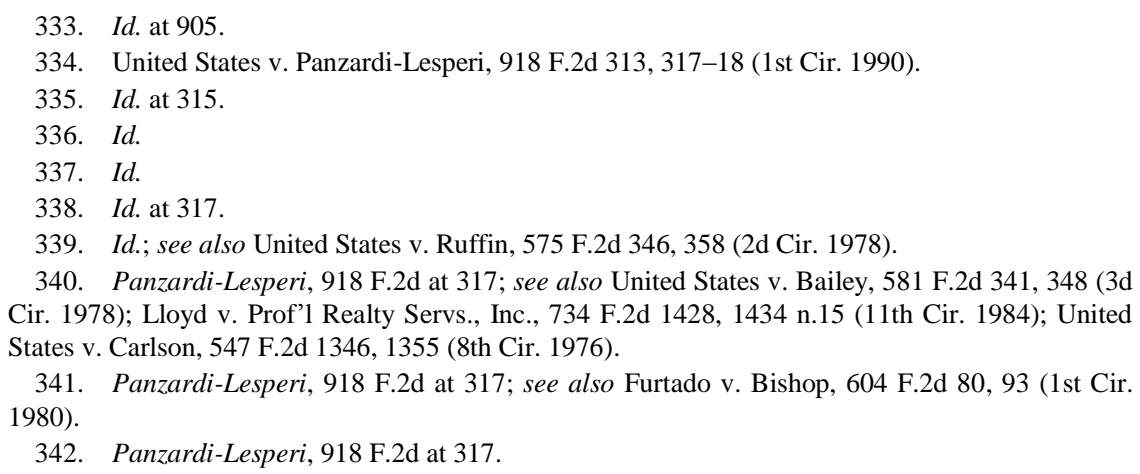


The First Circuit first observed that the legislative history of the residual exception provided little guidance on the inquiry (despite the fact that the language of the rule seems to provide a clear statement of the meaning of the notice requirement). ${ }^{343}$ The court then turned to the facts of the case to examine the adequacy of the mid-trial notice that was actually provided by the government. Of note to the court were the facts that the government had turned the grand jury testimony over to the defendant on the first day of trial, that the testimony wasn't introduced until the seventh day of trial, and that "[t]he statement [was] short and straightforward and was consistent with, and corroborated by, other evidence on the record." ${ }^{344}$ While none of these considerations appear remotely relevant to the Rule's clear wording that pretrial notice be provided, they do demonstrate fidelity to the principle notion of avoiding surprise and prejudice. The court affirmed the district court's utilization of the residual exception-demonstrating, again, the considerable discretion granted to district judges to admit residual hearsay. ${ }^{345}$ Indeed, the court noted that in light of the seven days worth of advance notice before admission, Panzardi-Lespier could "hardly claim surprise as to its content," and could not claim he had insufficient time to review the statement and prepare a defense accordingly. ${ }^{346}$ The court thus held that the flexible approach to pretrial notice applies to both the civil and criminal proceedings, and that allowing the jury to hear the grand jury testimony "is in harmony with both the interest of justice and the general purposes of the Rules of Evidence." 347 Panzardi-Lespier represents the prevailing approach to pretrial notice by which courts seem to excuse the plain language of the Rule in favor of an approach that finds notice is sufficient if it affords a party adequate time to prepare to defend the statement when it is introduced at trial.

In United States v. Bracey, the Fourth Circuit discussed the pretrial notice requirement in a case that also involved an appeal from a drug conspiracy conviction. ${ }^{348}$ Like Panzardi-Lespier, Bracey involved the introduction of grand jury testimony of a cooperating witness who

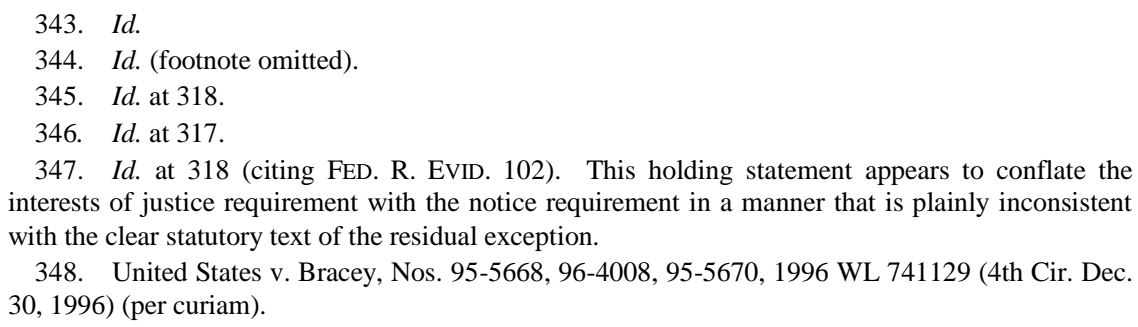

347. Id. at 318 (citing FED. R. EVID. 102). This holding statement appears to conflate the interests of justice requirement with the notice requirement in a manner that is plainly inconsistent with the clear statutory text of the residual exception.

348. United States v. Bracey, Nos. 95-5668, 96-4008, 95-5670, 1996 WL 741129 (4th Cir. Dec. 30, 1996) (per curiam). 
became unavailable in the weeks leading up to trial. ${ }^{349}$ Despite the government's desperate attempt to locate the witness before trial, she could not be found, and "[o]n the first Friday of the trial,... the government met ex parte with the trial judge and explained that [the witness] was missing." 350 Accordingly, the court had to determine whether it was an error for the district court to have admitted the evidence at trial despite the absence of pretrial notice.

The court began by stating that, in an "ordinary" case, the notice requirement should be strictly interpreted, but observed that "when 'reasonable steps' have been taken to locate an unavailable witness, and 'pretrial notice [is] wholly impracticable,' a court should grant 'notice flexibility' under Rule 804(b)(5)." 351 The court further noted that, while a continuance to the non-offering party is the "preferred remedy," there have been cases in which the notice requirement has been waived because "the defense was substantially aware of the gist of the testimony." 352 The notion that the Rules vest the court with the authority to waive an express notice requirement has, of course, no basis in the text of Rule 807. It is possible, however, that a court could look to Rule 102, which states that the Federal Rules of Evidence should be interpreted to "promote the development of evidence law, to the end of ascertaining the truth and securing a just determination.",353

After observing that the notice requirement could in fact be waived, the court went on to examine factors that could support the admission of residual hearsay "despite the lack of notice." 354 The Fourth Circuit found the following factors noteworthy: (1) that the government brought the unavailability of the witness to the court's attention; ${ }^{355}$ (2) that the government notified the defense of the witness's unavailability and its need to admit the grand jury testimony; (3) that the district court granted a two-day continuance upon the defense's request; (4) that the jury did

\footnotetext{
349. Id. at *1.

350. Id. at *3.

351. Id. at *4 (quoting United States v. Baker, 985 F.2d 1248, 1253 n.3 (4th Cir. 1993)).

352. Id. (citing Panzardi-Lespier, 918 F.2d at 317-15; United States v. Leslie, 542 F.2d 285, 291 (5th Cir. 1976)).

353. FED. R. EVID. 102.

354. Bracey, 1996 WL 741129 , at *4.

355. Id. It is unclear how it is remotely relevant that a party give notice to an opposing party of its intent to admit residual hearsay. Although not entirely clear from the opinion, the court seemed to believe it was necessary to give only ex parte warning, concluding that " $[\mathrm{t}] \mathrm{he}$ district court correctly decided that the possible danger to Chambers' safety justified a delay in informing the appellants of her disappearance from government custody." Id.
} 
not hear the testimony until six days after notice was provided; (5) that the defense had knowledge that the witness's testimony "would be a major aspect of the government's case, and knew the substance of [the] testimony"; and (6) that the district court "instructed the jury to give particular scrutiny to [the witness's] testimony." 356 Based on that combination of factors, the court concluded that the circumstances of the case rendered it "a strong case for "notice flexibility" and upheld the district court's use of the residual exception, despite the lack of pretrial notice. ${ }^{357}$ In so holding, the court departed from the strict approach, but it is not entirely clear what it was about the facts of the case or the witness's testimony that rendered the case extraordinary such that the default interpretation was rendered inapplicable.

Although courts have continued to liberally interpret the notice requirement under Rule 807, some courts have excluded residual hearsay because a party did not provide adequate, timely notice - not just notice of intent to introduce an out-of-court statement, but also of intent to do so under the residual exception. This approach is the minority approach, but it was endorsed by the Third Circuit in United States v. Pelullo. ${ }^{358}$ In Pelullo, Leonard Pelullo was convicted of wire fraud and RICO violations after a three-week jury trial and sentenced to twenty-four years in prison. ${ }^{359}$ Pelullo appealed, challenging numerous alleged errors at trial, including the allegedly erroneous introduction of hearsay evidence under the residual exception. ${ }^{360}$ On appeal, the government argued that it had satisfied the notice requirement by making the documents available

\footnotetext{
356. Id.

357. Id. (quoting United States v. Baker, 985 F.2d 1248, 1253 n.3 (4th Cir. 1993)).

358. United States v. Pelullo, 964 F.2d 193 (3d Cir. 1992).

359. Id. at 197.

360. Id. Interestingly, in the course of his direct appeals and collateral relief efforts, the Third Circuit addressed Pelullo's case six times over the course of thirteen years:

See, e.g., United States v. Pelullo, 964 F.2d 193 (3d Cir. 1992) ('Pelullo I') (reversing all but one of Pelullo's wire fraud convictions in the Eastern District of Pennsylvania due to the erroneous admission of unauthenticated bank records); United States v. Pelullo, 14 F.3d 881 (3d Cir. 1994) (reversing all of Pelullo's convictions on the ground that it was error to use prior conviction upheld in Pelullo $I$ as collateral estoppel to establish predicate offense in trial before second jury); United States v. Pelullo, 105 F.3d 117 (3d Cir. 1997) (reversing Pelullo's wire fraud and racketeering convictions by third jury based primarily on government's Brady violation in failing to disclose exculpatory evidence); United States v. Pelullo, 173 F.3d 131 (3d Cir. 1999) (affirming Pelullo’s wire fraud and racketeering convictions after his fourth trial in the Eastern District of Pennsylvania); United States v. Pelullo, 185 F.3d 863 (affirming the convictions in this case).
}

United States v. Pelullo, 399 F.3d 197, 202 n.4 (3d Cir. 2005), as amended (Mar. 8, 2005). This discussion involves his original appeal challenging admission under the residual exception in 1992. 
to Pelullo prior to trial and making it clear that they would be introduced at trial. ${ }^{361}$ The Third Circuit rejected the notion that notice of intent to introduce hearsay is sufficient under the requirements of the Rule $807 .{ }^{362}$ Instead, the court held that the rule requires "the proponent to give notice of its intention specifically to rely on the rule as grounds for admissibility." ${ }^{363}$ Accordingly, the court found that the testimony could not be introduced under the residual exception for failure to provide adequate notice of intent to rely on Rule $807 .{ }^{364}$ Clearly, this approach is contrary to the approach taken by the First and Fourth Circuits, and the propriety of this approach appears to have divided the circuit courts. ${ }^{365}$

Bracey and Panzardi-Lespier demonstrate a common approach where federal courts place greater importance on policy considerations than the text of the rule by adopting a flexible approach to pretrial notice - a trend that has been perpetuated since the inception of the residual exception. It appears that these courts are resistant to allow the procedural requirements of the rule to outweigh the purpose of the rule, thus admitting residual hearsay into evidence so long as an adverse party has adequate time to meet it. The harm to the truth-seeking function of a jury caused by excluding probative evidence further motivates these courts to admit evidence under the residual exception, despite the lack of pretrial notice. Pelullo, on the other hand, represents the strict interpretation of the pretrial notice requirement, one where residual hearsay will be excluded without litigation-specific notice, regardless of whether the defendant had an adequate opportunity to defend against it.

These cases illustrate the inconsistency of the text of the rule and the purpose of the rule. As observed in Residual Exceptions: the flexible approach is consistent with sound policy but is inconsistent with the text of the rule; the strict approach is consistent with the text of the rule but is not often sound as a matter of policy. ${ }^{366}$ Something's gotta give. This approach begs the question as to why Rule 807 has not yet been amended

\footnotetext{
361. Pelullo, 964 F.2d at 202.

362. Id.

363. Id. (citing United States v. Furst, 886 F.2d 558, 574 (3d Cir. 1989)).

364. Id. at 202-03.

365. The Third Circuit also cited two different circuit court opinions that differ on the extent to which the proponent of residual hearsay must notify an adversary of its intent to rely on the residual exception. Compare United States v. Tafollo-Cardenas, 897 F.2d 976, 980 (9th Cir. 1990) (requiring notice of intent to rely on the residual exception), with United States v. Benavente Gomez, 921 F.2d 378, 384 (1st Cir. 1990) (deciding to only require notice of intent to use hearsay statements). In Pelullo, the Third Circuit opted to follow the approach of the Ninth Circuit in Tafollo-Cardenas.

366. Residual Exceptions, supra note 1, at 905.
} 
so that these policy judgments by the courts are consistent with the plain mandate of the residual exception's text. Although history suggests that the residual exception will persist as one of the many rules that is intentionally misconstrued to further judicial views on wise public policy, this Article proposes the following minor amendment to Rule 807 (b) that will square the policy and the text of the rule. The text of Rule 807(b) should now read:

(b) (1) The statement is admissible only if, before the trial or hearing, the proponent gives an adverse party reasonable notice of the intent to offer the statement and its particulars, including the declarant's name and address, so that the party has a fair opportunity to meet it.

(2) In the event pretrial notice cannot be provided in accordance with paragraph (1), later notice consistent with the terms of paragraph (1) may be sufficient in a district judge's discretion so long as an adverse party has a fair opportunity to meet it, the proponent provides notice that the out-of-court statement will be admitted under Rule 807(a), and the notice is provided as soon as the proponent reasonably believes the out-of-court statement will be admitted at trial. ${ }^{367}$

\section{SURVEY OF STATE APPROACHES TO THE ADMISSION OF RESIDUAL HEARSAY}

A majority of states have followed the federal courts' lead and enacted a residual exception to the hearsay rule. ${ }^{368}$ Specifically, thirty states have adopted a residual exception applicable in state-court proceedings. ${ }^{369}$ Twenty states and the District of Columbia have not

367. The comments should provide that, in the event residual hearsay is admitted without pretrial notice, upon request, judges should provide the non-offering party the opportunity for a continuance of reasonable time such that the party has a fair opportunity to meet it.

368. See infra Appendix.

369. These states include: Alaska, Arizona, Arkansas, Colorado, Connecticut, Delaware, Georgia, Hawaii, Idaho, Iowa, Louisiana, Maryland, Michigan, Minnesota, Mississippi, Montana, Nebraska, Nevada, New Hampshire, New Mexico, North Carolina, North Dakota, Oklahoma, Oregon, Rhode Island, South Dakota, Utah, West Virginia, Wisconsin, and Wyoming. See infra Appendix. There is also a residual exception to the hearsay rule applicable in Puerto Rico, Guam, American Samoa, the U.S. Virgin Islands, and the Northern Mariana Islands. See infra Appendix. 
adopted a residual exception to the hearsay rule, ${ }^{370}$ with some of these states having offered an explicit, critical rejection of the notion of a catch-all exception. ${ }^{371}$ This Part provides a brief overview of various state-law approaches to admitting residual hearsay. An examination of the variations among state exceptions, ${ }^{372}$ as well as the differences between the federal and state residual exceptions, sheds light on the differences between the liberal federal approach to residual hearsay and a more cautious approach utilized in state courts. ${ }^{373}$

The number of states adopting a residual exception has appeared to level off in recent years. ${ }^{374}$ Most state residual exceptions, with certain outliers, mirror either Rule 807 or the dual residual exceptions-Rules 803(24) and 804(5) - that were in place before the 1997 amendment to the rules. Among those thirty states that have embraced the residual

370. Alabama, California, Florida, Illinois, Indiana, Kansas, Kentucky, Maine, Massachusetts, Missouri, New Jersey, New York, Ohio, Pennsylvania, South Carolina, Tennessee, Texas, Vermont, Virginia, and Washington. See infra Appendix.

371. For instance, the comments to the New Jersey Rules of Evidence explain:

The adoption of the federal rule was attended by substantial controversy and its application since its adoption has been disparate among the federal courts. See A.B.A. Section of Litigation, Emerging Problems Under the Federal Rules of Evidence 279-281 (1983). The adoption of Fed. R. Evid. 803(24), construable as a general relaxation rule, would represent a radical departure from New Jersey practice. The advantages and disadvantages of this departure are debatable.

N.J. R. EvID. 803 official comments.

Moreover, the comments to the Alabama Rules provide:

It should be noted that these rules do not include what is known as a "residual" or "catchall" exception to the hearsay rule. See Fed. R. Evid. 803(24). The committee expresses no position as to whether the Alabama Supreme Court may expand the number of hearsay exceptions by decision. See Dallas County v. Commercial Union Assurance Co., 286 F.2d 388 (5th Cir. 1961). However, the committee believes that any expansion in the number of hearsay exceptions generally should be accomplished, rather than on a case-by-case basis, by the Alabama Supreme Court's acting under its authority to prescribe rules of practice and procedure.

ALA. R. EvID. 803 advisory committee's notes.

372. For prior surveys of the residual exception, see Beaver, supra note 1, at 789 \& n.19; Leonard Birdsong, The Residual Exception to the Hearsay Rule-Has It Been Abused-A Survey Since the 1997 Amendment, 26 NovA L. ReV. 59, 65 (2001); G. Michael Fenner, The Residual Exception to the Hearsay Rule: The Complete Treatment, 33 CREIGHTON L. REV. 265 passim (2000).

373. See Birdsong, supra note 372, at 97 ("It is clear the state court judges in the civil cases reported on here have not abused their power with respect to the residual exception."). In fact, in the civil context, state court judges "appear to be very careful with respect to the admission of hearsay pursuant to the residual exception.” Id. at 95.

374. In 1993, Professor James Beaver observed that twenty-four states had refused to adopt the residual exception. Beaver, supra note 1, at 789. In 2001, Professor Leonard Birdsong found that twenty-eight states and Puerto Rico had adopted a residual exception. Birdsong, supra note 372, at 64 n.38. 
exception, thirteen have retained the dual residual exceptions based on the pre-1997 amendments - with one exception governing the out-ofcourt statements of unavailable declarants and the other under which availability of the declarant is immaterial. Eleven states followed Congress's lead in adopting a single, unified residual exception based on Rule 807 of the Federal Rules of Evidence.

Numerous states, which have been included in the thirty counted above, have enacted modified or limited residual exceptions. Connecticut's rule, for example, expressly provides that an out-of-court statement otherwise not admissible under an enumerated exception is admissible if "there is a reasonable necessity for the admission of the statement" and "the statement is supported by equivalent guarantees of trustworthiness and reliability that are essential to other evidence admitted under traditional exceptions to the hearsay rule." 375 Connecticut's rule also omits the pretrial notice requirement. ${ }^{376}$ Louisiana's residual exception only applies in civil cases in which the declarant is unavailable. ${ }^{377}$ The rule also permits a court to "authorize a delayed notice to be given" or "a recess, continuance, or other appropriate relief sufficient to enable [the nonoffering party] to prepare to meet the evidence" in the event that pretrial notice is "not practicable or failure to give notice is found by the court to have been excusable."378

Montana and Wisconsin preserve the distinction between Rule 803 and Rule 804; however, those states have repudiated most of the requirements for admitting residual hearsay, including the pretrial notice requirement. ${ }^{379}$ The Montana and Wisconsin residual exceptions provide simply for the admission of "[a] statement not specifically covered by any of the foregoing exceptions but having comparable circumstantial guarantees of trustworthiness." 380 This version of the residual exception "is identical to the Exception (24) contained in the version of the Federal Rules submitted to Congress." 381 The comments to the Montana rules explain that "the notice requirement is unnecessary because of discovery procedures and the discretion of the court in allowing advance rulings on

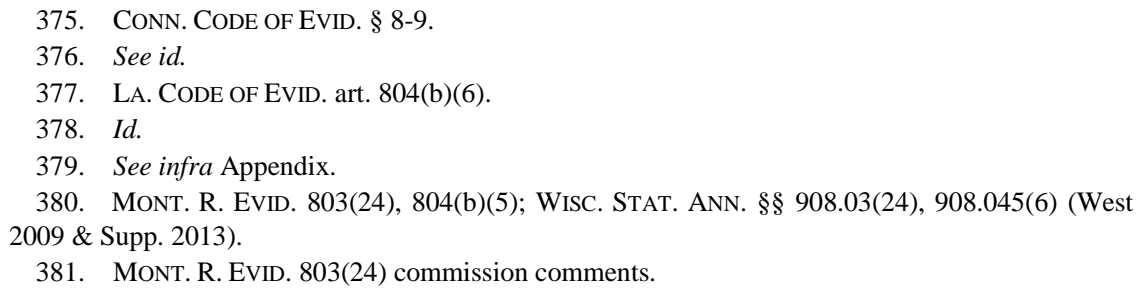


the admissibility of evidence." 382

Likewise, Nevada preserves the unavailable declarant distinction, yet its two residual exceptions differ slightly. Both exceptions provide that the enumerated exceptions under the Nevada Rules "are illustrative and not restrictive of the [residual] exception." 383 The Nevada exception, under which availability is immaterial, provides that "[a] statement is not excluded by the hearsay rule if its nature and the special circumstances under which it was made offer assurances of accuracy not likely to be enhanced by calling the declarant as a witness, even though the declarant is available." ${ }^{384}$ The Nevada exception applicable to unavailable declarants provides that such a statement is not excluded by the hearsay rule if "[i]ts nature and the special circumstances under which it was made offer strong assurances of accuracy." 385

New Hampshire omits the notice requirement if the out-of-court statement is being offered under Rule 803 , but requires notice of intent to offer the hearsay statement of an unavailable declarant under Rule $804 .^{386}$ In addition to the traditional requirements, Oklahoma's residual exception allows for notice to be provided during trial "if the court excuses pretrial notice for good cause." 387 Oklahoma's rule additionally requires that, in order to be admitted under the residual exception, a court must "state on the record the circumstances that support its determination of the admissibility of the statement offered." 388 Oklahoma's rule is also expressly limited to only "exceptional circumstances" not covered by the

\footnotetext{
382. Id. The Commission's comments further explained:

These amendments [offered by Congress to the originally proposed residual exception] can be criticized as follows: the requirement that the statement be offered as evidence of a "material" fact is redundant in requiring relevance as defined in Rule 401 and uses outmoded language so indicated in the Commission Comments to that rule. The requirement that the evidence be more probative on the point for which it is offered restricts the use of these types of exceptions by imposing a requirement similar to that of unavailability under Rule 804; this restriction would have the effect of severely limiting the instances in which the exception would be used and be impractical in the sense that a party would generally offer the strongest evidence available regardless of the existence of this requirement. The requirement that the general purposes of these rules and interests of justice will be served is unnecessarily repetitive in view of Rule 102. Finally, the notice requirement is unnecessary because of discovery procedures and the discretion of the court in allowing advance rulings on the admissibility of evidence. 
other enumerated exceptions under state law. ${ }^{389}$

While not included on the list of states that have adopted a residual exception, the Tennessee Rules acknowledge that, despite the absence of a codified residual exception, "[o]ccasionally... constitutional considerations require that a tribunal permit the accused in a criminal case to introduce trustworthy hearsay not falling within a traditional exception." 390 Additionally, both Florida and Ohio have limited exceptions that have been referred to as "quasi residual" exceptions. For instance, the Florida exception has been described as follows:

Section 90.803(23) of the Florida Evidence Code, allows the use of outof-court statements of a child, eleven years old or less, describing child abuse, neglect, or sexual abuse against the child, after the court holds a hearing to determine reliability of such statements. The statute is applicable whether the child is available or unavailable to testify. If the child is unavailable to testify and the statements are deemed to be reliable by the court, there must be other corroborating evidence of the offense before such statement may be used. There is also a ten day notice requirement that must be given to a defendant in a criminal case. Finally, the court, under this statute must make specific findings of fact on the record as to the basis for its ruling to admit or exclude the statements. Section 90.803(24) of the Florida Evidence Code is identical, except that it applies to elderly or disabled adults. ${ }^{39}$

Ohio's exception is similarly limited to out-of-court statements made by a child under the age of twelve that is "describing any sexual act performed by, with, or on the child or describing any act of physical violence directed against the child." 392 In order to be admissible under this exception, a court must find "the totality of the circumstances surrounding the making of the statement provides particularized guarantees of trustworthiness that make the statement at least as reliable as statements admitted" pursuant to the enumerated exceptions. ${ }^{393}$ The court must further find that the circumstances surrounding the statement "must establish that the child was particularly likely to be telling the truth when the statement was made and that the test of cross-examination would add little to the reliability of the statement." ${ }^{394}$ The child's testimony must not be reasonably obtainable by the proponent, as

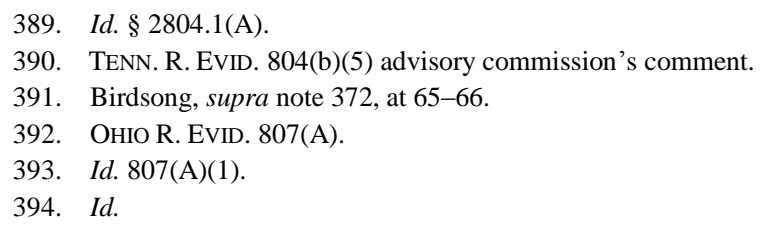


defined by Rule 807(B), and there must be "independent proof of the sexual act or act of physical violence." ${ }^{\prime 395}$ Lastly, the proponent must give written notice to all other parties at least ten days in advance of trial. ${ }^{396}$

Under state rules of evidence, the touchstone of admissibility under the residual exception remains the trustworthiness of the statement in light of the circumstances surrounding its making. As previously discussed, most states, either through common law, statute, or rule, have developed various factors that courts must consider when determining trustworthiness. ${ }^{397}$ These factors often vary, but state courts generally engage in a fact-specific inquiry looking at the totality of the circumstances surrounding the making of the out-of-court statement when assessing trustworthiness. ${ }^{398}$ Most states that have adopted a

\footnotetext{
395. Id. 807(A)(2)-(3); 807(B).
}

396. Id. 807(A)(4).

397. See Birdsong, supra note 372, at 95 ("These judges use the same analytical framework of seeking to determine whether there are appropriate indicia of reliability to give the statements trustworthiness.").

398. See, e.g., People v. Shifrin, 342 P.3d 506, 518-19 (Colo. App. 2014) (listing seven factors), cert. denied, No. 14SC268, 2015 WL 216599 (Colo. Jan. 12, 2015); State v. Weaver, 554 N.W.2d 240, 248 (Iowa 1996) (discussing factors to consider), overruled on other grounds by State v. Hallum, 585 N.W.2d 249 (Iowa 1998); State v. Nichols, 365 S.E.2d 561, 566-67 (N.C. 1988) (listing factors); State v. Jagielski, 467 N.W.2d 196, 198 (Wis. Ct. App. 1991) (listing factors). For instance, Colorado considers the following factors when determining trustworthiness under the state residual exception:

1) the nature and character of the statement; 2) the relationship of the parties; 3) the motivation of the declarant; 4) the circumstances under which the statement was made; 5) the knowledge and qualifications of the declarant; 6) the existence or lack of corroboration; and 7) the availability of the declarant at trial for cross-examination.

Shifrin, 342 P.3d at 518-19 (quoting Abdelsamed v. N.Y. Life Ins. Co., 857 P.2d 421, 426-27 (Colo. App. 1992), rev'd on other grounds, Hock v. N.Y. Life Ins. Co., 876 P.2d 1242 (Colo. 1994)).

North Carolina uses a similar list of factors to determine whether hearsay is sufficiently trustworthy to be admitted under the state residual exception:

(1) the declarant's personal knowledge of the underlying event; (2) the declarant's motivation to speak the truth; (3) whether the declarant recanted; and (4) the reason, within the meaning of Rule 804(a), for declarant's unavailability. ... [T] [Tis list is not inclusive.... Among the many factors which courts have considered are [5] the existence of corroborating evidence, and [6] the degree to which the proffered testimony has elements of enumerated exceptions to the hearsay rule. Nichols, 365 S.E.2d at 566-67 (citations omitted).

Under Iowa law, to support admission of a statement under the residual hearsay exception for having circumstantial guarantees of trustworthiness, trial courts consider, among other factors, "corroboration, reaffirming or recanting the statement by the declarant, credibility of the witness reporting the statement, and availability of the declarant for cross-examination." Weaver, 554 N.W.2d at 248 .

When considering the admissibility of a child's hearsay statements under the residual exception, Wisconsin courts consider: 
residual exception have some form of probativeness requirement, and almost all have a notice requirement similar to Rule 807(b). ${ }^{399}$

Twenty states have opted against adopting a catchall exception under their rules of evidence. ${ }^{400}$ Given the number of states refusing to enact a residual exception to the hearsay rule, the views expressed by the Supreme Judicial Court of Massachusetts in Commonwealth v. Pope $e^{401}$ appear to be shared by a great number of state courts and legislatures. In Pope, the court rejected the state's urging for the court to adopt a residual exception modeled after the federal rule, stating "we see no reason to adopt the rather broad Federal formulation as a general rule." ${ }^{.42}$ The court went on to conclude, "[w]e do not believe the administration of justice in this Commonwealth would be advanced by adoption of a rule whose application in practice has been marked by conflicting and illogical results." ${ }^{\circ 03}$

In sum, this survey demonstrates that there is considerable debate among the states regarding the propriety of the residual exception. Thirty states, and various U.S. territories, have adopted the residual exception in some form, while twenty states and the District of Columbia have rejected the exception. Two states have rejected the exception but provide for a similar exception for statements of child victims. One of those states, Florida, also includes an exception for statements made by elderly or disabled victims. Seven states have a modified residual exception, two of which require only circumstantial guarantees of

(1) the attributes of the child making the statements, including age, comprehension, verbal ability and motivations; (2) the person to whom statements were made, the relationship to the child and potential motivations to fabricate or distort; (3) the circumstances under which the statements were made, including the relation to the time of the assault, the availability of a person in whom the child might confide and other contextual factors relating to the statements' trustworthiness; (4) the content of statements, noting any sign of deceit, falsity, and whether they reveal a knowledge of matters not ordinarily attributable to a child of similar age; and (5) other corroborating evidence, such as physical evidence of an assault, statements made to others and opportunity or motive of the defendant. Jagielski, 467 N.W.2d at 198.

399. See Birdsong, supra note 372, at 65 (observing that both "Nevada and Wisconsin omit the notice requirement of the federal rule").

400. See infra Appendix. Those states are: Alabama, California, Florida, Illinois, Indiana, Kansas, Kentucky, Maine, Massachusetts, Missouri, New Jersey, New York, Ohio, Pennsylvania, South Carolina, Tennessee, Texas, Vermont, Virginia, and Washington. Florida and Ohio have limited residual exceptions that apply in very limited situations. See supra notes 391-96 and accompanying text.

401. Commonwealth v. Pope, 491 N.E.2d 240, 244-45 (Mass. 1986).

402. Id. at 244 (citing Residual Exceptions, supra note 1, at 867).

403. Id. at 244 n.9. 
trustworthiness for admissibility.

Much can be learned about the purpose and function of the residual exception to the hearsay rule by examining these various state approaches. What does appear clear based on a survey of the subtle distinctions among the state-law approaches to residual hearsay is that litigants would do well to closely monitor the jurisdiction-specific, residual-exception case law that will be governing their adversarial proceedings.

\section{CONCLUSION}

This Article serves to update Professor Sonenshein's in-depth analysis of the residual exception to the hearsay rule found in his 1982 article Residual Exceptions. Since Residual Exceptions was first published, the rule governing the admission of residual hearsay has undergone some change; it has been twice amended and has been subsequently adopted in some form in thirty states.

Yet not all has changed. The various requirements of the rule continue to be interpreted in a manner inconsistent with the intent that the exception be used only in extraordinary circumstances, and the notice provision is still desperately in need of an amendment. Ultimately what remains unchanged since the early interpretations of the rule is the considerable discretion trial courts are granted in determining the admissibility of hearsay under the residual exception-discretion that, when combined with the harmless error doctrine, is rarely disturbed by appellate courts. In that light, the above survey of the residual exception calls to mind the out-of-court statements of the storied English legal scholar Lord Edward Coke: "It is the function of a judge not to make but to declare the law, according to the golden mete-wand of the law and not by the crooked cord of discretion." 404

\section{Appendix: State Residual Exceptions}

404. 1 EdWARd CoKe ET AL., InStitutes OF THE LAWS OF ENGLAND 51 (16th ed. 1809). 


\begin{tabular}{|c|c|c|}
\hline$\underline{\text { State }}$ & $\frac{\text { Residual }}{\text { Exception }}$ & State Exception $^{405}$ \\
\hline Alabama & No & $\begin{array}{l}\text { Committee Note: } \\
\text { It should be noted that these rules do not include } \\
\text { what is known as a "residual" or "catchall" } \\
\text { exception to the hearsay rule. See Fed. R. Evid. } \\
803(24) \text {. The committee expresses no position as } \\
\text { to whether the Alabama Supreme Court may } \\
\text { expand the number of hearsay exceptions by } \\
\text { decision. See Dallas County v. Commercial } \\
\text { Union Assurance Co., } 286 \text { F.2d } 388 \text { (5th Cir. } \\
\text { 1961). However, the committee believes that any } \\
\text { expansion in the number of hearsay exceptions } \\
\text { generally should be accomplished, rather than on a } \\
\text { case-by-case basis, by the Alabama Supreme } \\
\text { Court's acting under its authority to prescribe } \\
\text { rules of practice and procedure. } \\
\text { ALA. R. EvID. } 803 \text { advisory committee's notes. }\end{array}$ \\
\hline Alaska & Yes & $\begin{array}{l}\text { Alaska Rules 803(23) \& 804(b)(5) } \\
\text { [Modeled after Federal Rule] }\end{array}$ \\
\hline Arizona & Yes & $\begin{array}{l}\text { Arizona Rule } 807 \\
\text { [Modeled after Federal Rule] }\end{array}$ \\
\hline Arkansas & Yes & $\begin{array}{l}\text { Arkansas Rules 803(24) \& 804(b)(5) } \\
\text { [Modeled after Federal Rule] }\end{array}$ \\
\hline California & No & \\
\hline Colorado & Yes & $\begin{array}{l}\text { Colorado Rule } \mathbf{8 0 7} \\
\text { [Modeled after Federal Rule] } \\
\text { Colorado considers the following factors when } \\
\text { determining trustworthiness under the state } \\
\text { residual exception: } \\
\begin{array}{l}\text { 1) the nature and character of the statement; 2) } \\
\text { the relationship of the parties; 3) the }\end{array}\end{array}$ \\
\hline
\end{tabular}

405. For brevity's sake, the language of the rule in jurisdictions that have residual exceptions identical or nearly identical to Rule 807, or former Rules 803(24) and 804(5), has not been included in the Appendix. Also, language taken directly from the state statute, or its comments, may not be encased in quotation marks, whereas language from state cases interpreting the statute is in quotation marks or formatted as a block quote. This is to save space in the chart as well as for ease of reading. 


\begin{tabular}{|c|c|c|}
\hline & & $\begin{array}{l}\text { motivation of the declarant; 4) the } \\
\text { circumstances under which the statement was } \\
\text { made; 5) the knowledge and qualifications of } \\
\text { the declarant; 6) the existence or lack of } \\
\text { corroboration; and 7) the availability of the } \\
\text { declarant at trial for cross-examination. } \\
\text { People v. Shifrin, } 342 \text { P.3d 506, 518-19 (Colo. } \\
\text { App. 2014) (quoting Abdelsamed v. N.Y. Life Ins. } \\
\text { Co., } 857 \text { P.2d 421, 426-27 (Colo. App. 1992), } \\
\text { rev'd on other grounds, Hock v. N.Y. Life Ins. } \\
\text { Co., 876 P.2d 1242 (Colo. 1994)), cert. denied, } \\
\text { No. 14SC268, } 2015 \text { WL 216599 (Colo. Jan. 12, } \\
\text { 2015). }\end{array}$ \\
\hline Connecticut & $\begin{array}{l}\text { Yes, but } \\
\text { modified }\end{array}$ & $\begin{array}{l}\text { A statement that is not admissible under any of the } \\
\text { foregoing exceptions is admissible if the court } \\
\text { determines that (1) there is a reasonable necessity } \\
\text { for the admission of the statement, and (2) the } \\
\text { statement is supported by equivalent guarantees of } \\
\text { trustworthiness and reliability that are essential to } \\
\text { other evidence admitted under traditional } \\
\text { exceptions to the hearsay rule. } \\
\text { CONN. CODE OF EVID. § 8-9. }\end{array}$ \\
\hline Delaware & Yes & $\begin{array}{l}\text { Delaware Rule } 807 \\
\text { [Modeled after Federal Rule] }\end{array}$ \\
\hline Florida & No & $\begin{array}{l}\text { For a discussion of Florida's quasi-residual } \\
\text { exception, see supra text accompanying note } 391 \text {. }\end{array}$ \\
\hline Georgia & Yes & $\begin{array}{l}\text { Georgia Code Annotated section 24-8-807 } \\
\text { [Modeled after Federal Rule] }\end{array}$ \\
\hline Hawaii & $\begin{array}{l}\text { Yes, but } \\
\text { without } \\
\text { materiality } \\
\text { requirement }\end{array}$ & $\begin{array}{l}\text { Other exceptions. A statement not specifically } \\
\text { covered by any of the exceptions in this paragraph } \\
\text { (b) but having equivalent circumstantial } \\
\text { guarantees of trustworthiness, if the court } \\
\text { determines that (A) the statement is more } \\
\text { probative on the point for which it is offered than } \\
\text { any other evidence which the proponent can } \\
\text { procure through reasonable efforts, and (B) the } \\
\text { general purposes of these rules and the interests of } \\
\text { justice will best be served by admission of the } \\
\text { statement into evidence. However, a statement } \\
\text { may not be admitted under this exception unless }\end{array}$ \\
\hline
\end{tabular}




\begin{tabular}{|c|c|c|}
\hline & & $\begin{array}{l}\text { the proponent of it makes known to the adverse } \\
\text { party sufficiently in advance of the trial or hearing } \\
\text { to provide the adverse party with a fair } \\
\text { opportunity to prepare to meet it, the proponent's } \\
\text { intention to offer the statement and the particulars } \\
\text { of it, including the name and address of the } \\
\text { declarant. } \\
\text { HAW. R. EvID. 803(b)(24). The residual } \\
\text { exception for unavilable declarants contains } \\
\text { materially similar language. HAW. R. EVID. } \\
\text { 804(b)(8). }\end{array}$ \\
\hline Idaho & Yes & $\begin{array}{l}\text { Idaho Rules } \mathbf{8 0 3 ( 2 4 ) \& ~ 8 0 4 ( b ) ( 6 )} \\
\text { [Modeled after Federal Rule] }\end{array}$ \\
\hline Illinois & No & \\
\hline Indiana & No & \\
\hline Iowa & Yes & $\begin{array}{l}\text { Iowa Rules of Evidence Rule } \mathbf{5 . 8 0 7} \\
\text { [Modeled after Federal Rule] } \\
\text { In determining whether a hearsay statement is } \\
\text { trustworthy, to support admission of the statement } \\
\text { under the residual hearsay exception for having } \\
\text { circumstantial guarantees of trustworthiness, the } \\
\text { trial court considers: corroboration, reaffirming or } \\
\text { recanting the statement by the declarant, } \\
\text { credibility of the witness reporting the statement, } \\
\text { and the availability of the declarant for cross- } \\
\text { examination. State v. Weaver, } 554 \text { N.W.2d } 240 \text {, } \\
248 \text { (Iowa 1996), overruled on other grounds by } \\
\text { State v. Hallun, 585 N.W.2d } 249 \text { (Iowa 1998). }\end{array}$ \\
\hline Kansas & No & \\
\hline Kentucky & No & \\
\hline Louisiana & $\begin{array}{l}\text { Yes, but } \\
\text { limited }\end{array}$ & $\begin{array}{l}\text { Only applies in civil cases where the declarant is } \\
\text { unavailable, and the statute reads as follows: } \\
\text { Other exceptions. In a civil case, a statement not } \\
\text { specifically covered by any of the foregoing } \\
\text { exceptions if the court determines that considering } \\
\text { all pertinent circumstances in the particular case } \\
\text { the statement is trustworthy, and the proponent of }\end{array}$ \\
\hline
\end{tabular}




\begin{tabular}{|c|c|c|}
\hline & & $\begin{array}{l}\text { the evidence has adduced or made a reasonable } \\
\text { effort to adduce all other admissible evidence to } \\
\text { establish the fact to which the proffered statement } \\
\text { relates and the proponent of the statement makes } \\
\text { known in writing to the adverse party and to the } \\
\text { court his intention to offer the statement and the } \\
\text { particulars of it, including the name and address of } \\
\text { the declarant, sufficiently in advance of the trial or } \\
\text { hearing to provide the adverse party with a fair } \\
\text { opportunity to prepare to meet it. If, under the } \\
\text { circumstances of a particular case, giving of this } \\
\text { notice was not practicable or failure to give notice } \\
\text { is found by the court to have been excusable, the } \\
\text { court may authorize a delayed notice to be given, } \\
\text { and in that event the opposing party is entitled to a } \\
\text { recess, continuance, or other appropriate relief } \\
\text { sufficient to enable him to prepare to meet the } \\
\text { evidence. } \\
\text { LA. CoDE EvID. art. } 804(B)(6) \text {. }\end{array}$ \\
\hline Maine & No & \\
\hline Maryland & Yes & $\begin{array}{l}\text { Maryland Rules of Evidence Rule 5-803(b)(24) } \\
\text { [Modeled after Federal Rule] } \\
\text { Committee note: The residual exception provided } \\
\text { by Rule 5-803(b)(24) does not contemplate an } \\
\text { unfettered exercise of judicial discretion, but it } \\
\text { does provide for treating new and presently } \\
\text { unanticipated situations which demonstrate a } \\
\text { trustworthiness within the spirit of the specifically } \\
\text { stated exceptions. Within this framework, room is } \\
\text { left for growth and development of the law of } \\
\text { evidence in the hearsay area, consistently with the } \\
\text { broad purposes expressed in Rule 5-102. } \\
\text { It is intended that the residual hearsay } \\
\text { exception will be used very rarely, and only in } \\
\text { exceptional circumstances. The Committee does } \\
\text { not intend to establish a broad license for trial } \\
\text { judges to admit hearsay statements that do not fall } \\
\text { within one of the other exceptions contained in }\end{array}$ \\
\hline
\end{tabular}




\begin{tabular}{|c|c|c|}
\hline & & $\begin{array}{l}\text { Rules 5-803 and 5-804 (b). } \\
\text { MD. R. EVID. 5-803(b)(24) committee's note. }\end{array}$ \\
\hline Massachusetts & No & 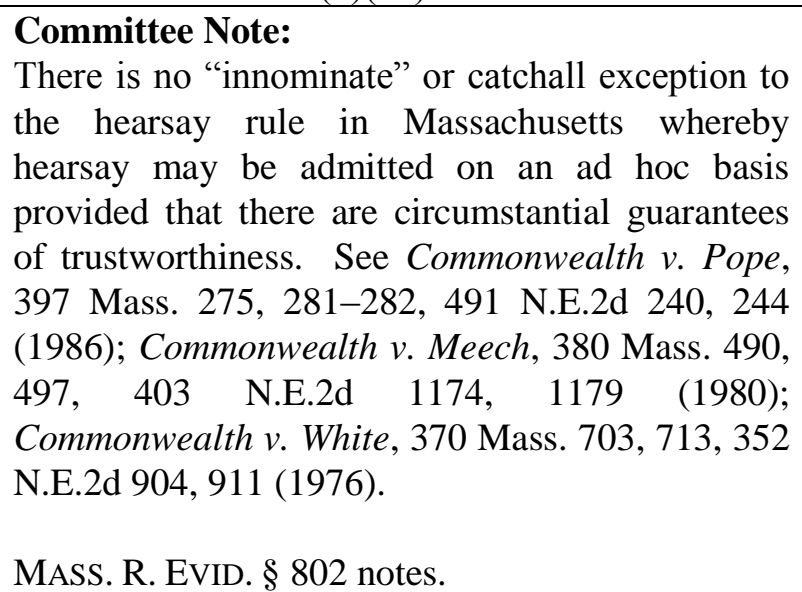 \\
\hline Michigan & Yes & $\begin{array}{l}\text { Michigan Rules of Evidence } \\
\text { 804(b)(7) } \\
{[\text { Modeled after Federal Rule] }}\end{array}$ \\
\hline Minnesota & Yes & $\begin{array}{l}\text { Minnesota Rules of Evidence } \mathbf{8 0 7} \\
\text { [Modeled after Federal Rule] }\end{array}$ \\
\hline Mississippi & Yes & $\begin{array}{l}\text { Mississippi Rules of Evidence } \mathbf{8 0 3}(\mathbf{2 4}) \text { \& } \\
\text { 804(b)(5) } \\
\text { [Modeled after Federal Rule] } \\
\text { Committee Note: } \\
\text { The rule reflects the realization that the law is not } \\
\text { stagnant. As the FRE Advisory Committee's Note } \\
\text { indicates, it would be presumptuous to assume } \\
\text { that the contemporary legal community has } \\
\text { enumerated every single hearsay exception which } \\
\text { possibl could exist. The exceptions are not a } \\
\text { closed system, and Rule } 803(24) \text { and its } \\
\text { counterpart Rule 804(b)(5) allow for the future } \\
\text { development of the law when the guarantees of } \\
\text { reliability and trustworthiness can be found. } \\
\text { While these two rules allow for judicial discretion, } \\
\text { they do not permit an unfettered discretion which } \\
\text { could ultimately devour the hearsay rule. Before } \\
\text { admitting statements under this rule, the judge } \\
\text { must make a finding that the statements being }\end{array}$ \\
\hline
\end{tabular}




\begin{tabular}{|c|c|c|}
\hline & & $\begin{array}{l}\text { offered are sufficiently trustworthy and reliable. } \\
\text { See Cummins v. State, } 515 \text { So. } 2 \text { d } 869 \text { (Miss. } \\
\text { 1987). One of the clearest examples of the } \\
\text { circumstances meeting the criteria of Rule } 803(24) \\
\text { is found in Dallas County v. Commercial Union } \\
\text { Assur. Co., } 286 \text { F.2d } 388 \text { (5th Cir. 1961). } \\
\text { Miss. R. EVID. 803(24) advisory committee's } \\
\text { comment. }\end{array}$ \\
\hline Missouri & No & \\
\hline Montana & $\begin{array}{l}\text { Yes, but } \\
\text { modified } \\
\text { No } \\
\text { probative- } \\
\text { ness, } \\
\text { materiality, } \\
\text { or notice } \\
\text { requirement }\end{array}$ & $\begin{array}{l}\text { "Other exceptions. A statement not specifically } \\
\text { covered by any of the foregoing exceptions but } \\
\text { having comparable circumstantial guarantees of } \\
\text { trustworthiness." MoNT. R. EVID. 803(24), } \\
804(\text { b)(5). } \\
\text { Committee Note: } \\
\text { This exception is identical to the Exception } \\
\text { (24) contained in the version of the Federal Rules } \\
\text { submitted to Congress. Congress amended that } \\
\text { exception to require, in addition to circumstantial } \\
\text { guarantees of trustworthiness, that the statement is } \\
\text { offered as evidence of material fact, that it is more } \\
\text { probative on the point for which it is offered than } \\
\text { any other evidence, that the general purposes of } \\
\text { the rules and interests of justice will be served, } \\
\text { and that notice be served on the adversary. } \\
\text { The Commission believed this exception } \\
\text { should allow "room for growth and development } \\
\text { of the law of evidence in the area of hearsay" and } \\
\text { that the amendments by Congress are too } \\
\text { restrictive and contrary to the purpose of the } \\
\text { provision. These amendments can be criticized as } \\
\text { follows: the requirement that the statement be } \\
\text { offered as evidence of a "material" fact is } \\
\text { redundant in requiring relevance as defined in } \\
\text { Rule } 401 \text { and uses outmoded language so } \\
\text { indicated in the Commission Comments to that } \\
\text { rule. The requirement that the evidence be more } \\
\text { probative on the point for which it is offered }\end{array}$ \\
\hline
\end{tabular}




\begin{tabular}{|c|c|c|}
\hline & & $\begin{array}{l}\text { restricts the use of these types of exceptions by } \\
\text { imposing a requirement similar to that of } \\
\text { unavailability under Rule 804; this restriction } \\
\text { would have the effect of severely limiting the } \\
\text { instances in which the exception would be used } \\
\text { and be impractical in the sense that a party would } \\
\text { generally offer the strongest evidence available } \\
\text { regardless of the existence of this requirement. } \\
\text { The requirement that the general purposes of these } \\
\text { rules and interests of justice will be served is } \\
\text { unnecessarily repetitive in view of Rule 102. } \\
\text { Finally, the notice requirement is unnecessary } \\
\text { because of discovery procedures and the } \\
\text { discretion of the court in allowing advance rulings } \\
\text { on the admissibility of evidence. } \\
\text { The guarantee of trustworthiness set out in the } \\
\text { Commission Comments to each of the other } \\
\text { exceptions is the criteria to be used in determining } \\
\text { whether to apply this open-ended exception and } \\
\text { find a "comparable circumstantial guarantee of } \\
\text { trustworthiness." } \\
\text { There is no equivalent Montana law to this } \\
\text { exception. The adoption of this exception changes } \\
\text { existing Montana law to the extent that it allows a } \\
\text { court to admit hearsay because an equivalent } \\
\text { guarantee of trustworthiness exists even though } \\
\text { there is no specific exception allowing it. } \\
\text { MoNT. R. EviD. 803 commission comments } \\
\text { (citations omitted). }\end{array}$ \\
\hline Nebraska & Yes & $\begin{array}{l}\text { Nebraska Rules 27-803(23) \& 27-804(2)(e) } \\
\text { [Modeled after Federal Rule] }\end{array}$ \\
\hline Nevada & $\begin{array}{l}\text { Yes, but } \\
\text { modified }\end{array}$ & $\begin{array}{l}\text { Availability Immaterial Exception: } \\
\text { 1. A statement is not excluded by the hearsay rule } \\
\text { if its nature and the special circumstances under } \\
\text { which it was made offer assurances of accuracy } \\
\text { not likely to be enhanced by calling the declarant } \\
\text { as a witness, even though the declarant is } \\
\text { available. } \\
\text { 2. The provisions of NRS } 51.085 \text { to } 51.305 \text {, } \\
\text { inclusive, are illustrative and not restrictive of the }\end{array}$ \\
\hline
\end{tabular}




\begin{tabular}{|c|c|c|}
\hline & & $\begin{array}{l}\text { exception provided by this section. } \\
\text { NEV. REV. STAT. ANN. } \$ 51.075 \text { (West, Westlaw } \\
\text { through the end of the 78th Reg. Sess.). } \\
\text { Unavailability Exception: } \\
\text { 1. A statement is not excluded by the hearsay rule } \\
\text { if: } \\
\text { (a) Its nature and the special circumstances under } \\
\text { which it was made offer strong assurances of } \\
\text { accuracy; and } \\
\text { (b) The declarant is unavailable as a witness. } \\
\text { 2. The provisions of NRS } 51.325 \text { to } 51.355 \text {, } \\
\text { inclusive, are illustrative and not restrictive of the } \\
\text { exception provided by this section. } \\
\text { NEV. REV. STAT. ANN. } \S 51.315 \text { (West, Westlaw } \\
\text { through the end of the } 78 t h \text { Reg. Sess.). }\end{array}$ \\
\hline $\begin{array}{l}\text { New } \\
\text { Hampshire }\end{array}$ & $\begin{array}{l}\text { Yes, but no } \\
\text { notice } \\
\text { provision } \\
\text { where } \\
\text { availability } \\
\text { of declarant } \\
\text { is } \\
\text { immaterial }\end{array}$ & $\begin{array}{l}\text { New Hampshire Rules of Evidence } \mathbf{8 0 3}(\mathbf{2 4}) \mathbf{\&} \\
\text { 804(b)(6)} \\
\text { [Modeled after Federal Rule] } \\
\text { Committee Note: } \\
\text { As indicated in the early case of Lane v. Hill, } \\
68 \text { N.H. 275, } 44 \text { A. } 393 \text { (1895), the New } \\
\text { Hampshire courts have for some time followed a } \\
\text { liberal approach with respect to the admissibility } \\
\text { of hearsay statements. Their philosophy was best } \\
\text { expressed by Chief Justice Kenison in Perry } v \text {. } \\
\text { Parker, } 101 \text { N.H. } 295,141 \text { A.2d } 883 \text { (1958). He } \\
\text { stated that "The fundamental inquiry is not the } \\
\text { name or number of the exceptions to the hearsay } \\
\text { rule, but whether "under the circumstances the } \\
\text { evidence satisfies the reasons which lie behind the } \\
\text { exceptions." Id. at 297, } 141 \text { A.2d at } 884 \text {, quoting } \\
\text { McCormick, Evidence (1954) at } 633 \text {. The Chief } \\
\text { Justice went on to quote and refer to two earlier } \\
\text { cases, Gagnon v. Pronovost, } 97 \text { N.H. } 500,92 \text { A.2d } \\
904 \text { (1952), and Hutchins v. Berry, } 75 \text { N.H. } 416 \text {, } \\
75 \text { A. } 650 \text { (1910). } \\
\text { As stated by the Gagnon Court, "We believe }\end{array}$ \\
\hline
\end{tabular}




\begin{tabular}{|c|c|c|}
\hline & & $\begin{array}{l}\text { the sensible test to determine whether this } \\
\text { evidence should have been admitted was } \\
\text { suggested by Chief Justice Peaslee in Hutchins } v \text {. } \\
\text { Berry: "Is this account so lacking in apparent } \\
\text { trustworthiness that it cannot be wholly rejected, } \\
\text { or should it be admitted, and the objections to it } \\
\text { used to detract from its weight? The latter course } \\
\text { seems the more reasonable." Gagnon at 503, } 92 \\
\text { A.2d at } 906 \text {, quoting Hutchins at } 419,75 \text { A. } 650 \text {. } \\
\text { N.H. R. EVID. } 803 \text { reporter's note. }\end{array}$ \\
\hline New Jersey & No & $\begin{array}{l}\text { Committee Note: } \\
\text { (24) Other exceptions: Not Adopted. Fed.R.Evid. } \\
\text { 803(24), which creates a general hearsay } \\
\text { exception for statements not covered by a specific } \\
\text { hearsay rule, provided they are attended by } \\
\text { 'equivalent circumstantial guarantees of } \\
\text { trustworthiness' and are the most probative } \\
\text { evidence reasonably available, and provided } \\
\text { further that other stated criteria are met, was not } \\
\text { adopted. The adoption of the federal rule was } \\
\text { attended by substantial controversy and its } \\
\text { application since its adoption has been disparate } \\
\text { among the federal courts. See A.B.A. Section of } \\
\text { Litigation, Emerging Problems Under the Federal } \\
\text { Rules of Evidence } 279-281 \text { (1983). The adoption } \\
\text { of Fed. R. Evid. } 803 \text { (24), construable as a general } \\
\text { relaxation rule, would represent a radical } \\
\text { departure from New Jersey practice. } \\
\text { advantages and disadvantages of this departure are } \\
\text { debatable. For the same reason, Fed. R. Evid. } \\
\text { 804(b)(5) was not adopted. It should be noted that } \\
\text { a broad relaxation rule proposed as Rule 2(4) in } \\
\text { The 1963 Report at } 9 \text { was rejected. } \\
\text { N.J. R. EviD. } 803 \text { official comments. }\end{array}$ \\
\hline New Mexico & Yes & $\begin{array}{l}\text { New Mexico Rule 11-807 } \\
\text { [Modeled after Federal Rule] }\end{array}$ \\
\hline New York & No & \\
\hline North & Yes & North Carolina Rules 803(24) \& 804(b)(5) \\
\hline
\end{tabular}




\begin{tabular}{|c|c|c|}
\hline Carolina & & $\begin{array}{l}\text { [Modeled after Federal Rule] } \\
\text { North Carolina considers the following factors to } \\
\text { determine whether hearsay is sufficiently } \\
\text { trustworthy to be admitted under the state residual } \\
\text { exception: } \\
\text { (1) the declarant's personal knowledge of the } \\
\text { underlying event; (2) the declarant's } \\
\text { motivation to speak the truth; (3) whether the } \\
\text { declarant recanted; (4) the reason ... for } \\
\text { declarant's unavailability ... [5] existence of } \\
\text { corroborating evidence, and [6] the degree to } \\
\text { which the proffered testimony has elements of } \\
\text { enumerated exceptions to the hearsay rule. } \\
\text { State v. Nichols, } 365 \text { S.E.2d } 561,566-67 \text { (N.C. } \\
\text { 1988) (citations omitted). }\end{array}$ \\
\hline North Dakota & Yes & $\begin{array}{l}\text { North Dakota Rules of Evidence } 807 \\
\text { [Modeled after Federal Rule] }\end{array}$ \\
\hline Ohio & $\begin{array}{l}\text { No, but } \\
\text { there is a } \\
\text { hearsay } \\
\text { exception } \\
\text { similar to } \\
\text { the residual } \\
\text { exception } \\
\text { governing } \\
\text { the } \\
\text { admission } \\
\text { of out-of- } \\
\text { court } \\
\text { statements } \\
\text { of children } \\
\text { in child } \\
\text { abuse cases }\end{array}$ & $\begin{array}{l}\text { Hearsay exceptions; Child statements in abuse } \\
\text { cases } \\
\text { (A) An out-of-court statement made by a child } \\
\text { who is under twelve years of age at the time of } \\
\text { trial or hearing describing any sexual act } \\
\text { performed by, with, or on the child or describing } \\
\text { any act of physical violence directed against the } \\
\text { child is not excluded as hearsay under Evid. R. } \\
802 \text { if all of the following apply: } \\
\text { (1) The court finds that the totality of the } \\
\text { circumstances surrounding the making of the } \\
\text { statement provides particularized guarantees of } \\
\text { trustworthiness that make the statement at least as } \\
\text { reliable as statements admitted pursuant to Evid. } \\
\text { R. } 803 \text { and } 804 \text {. The circumstances must establish } \\
\text { that the child was particularly likely to be telling } \\
\text { the truth when the statement was made and that } \\
\text { the test of cross-examination would add little to } \\
\text { the reliability of the statement. In making its } \\
\text { determination of the reliability of the statement, } \\
\text { the court shall consider all of the circumstances } \\
\text { surrounding the making of the statement, }\end{array}$ \\
\hline
\end{tabular}




\begin{tabular}{|c|c|c|}
\hline & & $\begin{array}{l}\text { including but not limited to spontaneity, the } \\
\text { internal consistency of the statement, the mental } \\
\text { state of the child, the child's motive or lack of } \\
\text { motive to fabricate, the child's use of terminology } \\
\text { unexpected of a child of similar age, the means by } \\
\text { which the statement was elicited, and the lapse of } \\
\text { time between the act and the statement. In making } \\
\text { this determination, the court shall not consider } \\
\text { whether there is independent proof of the sexual } \\
\text { act or act of physical violence. } \\
\text { (2) The child's testimony is not reasonably } \\
\text { obtainable by the proponent of the statement. } \\
\text { (3) There is independent proof of the sexual act or } \\
\text { act of physical violence. } \\
\text { (4) At least ten days before the trial or hearing, a } \\
\text { proponent of the statement has notified all other } \\
\text { parties in writing of the content of the statement, } \\
\text { the time and place at which the statement was } \\
\text { made, the identity of the witness who is to testify } \\
\text { about the statement, and the circumstances } \\
\text { surrounding the statement that are claimed to } \\
\text { indicate its trustworthiness. } \\
\text { OHIO R. EviD. } 807 \text { (A). }\end{array}$ \\
\hline Oklahoma & Yes & $\begin{array}{l}\text { Hearsay Exception-Exceptional circumstances } \\
\text { A. In exceptional circumstances a statement not } \\
\text { covered by Section } 2803,2804,2805 \text {, or } 2806 \text { of } \\
\text { this title but possessing equivalent, though not } \\
\text { identical, circumstantial guarantees of } \\
\text { trustworthiness, is not excluded by the hearsay } \\
\text { rule if the court determines that: } \\
\text { 1. The statement is offered as evidence of a fact } \\
\text { of consequence; } \\
\text { 2. The statement is more probative on the point } \\
\text { for which it is offered than any other evidence that } \\
\text { the proponent can procure through reasonable } \\
\text { efforts; and }\end{array}$ \\
\hline
\end{tabular}




\begin{tabular}{|l|l|l|}
\hline & $\begin{array}{l}\text { 3. The general purposes of this Code and the } \\
\text { interests of justice will best be served by } \\
\text { admission of the statement into evidence. }\end{array}$ \\
B. The court shall state on the record the \\
circumstances that support its determination of the \\
admissibility of the statement offered pursuant to \\
subsection A of this section. \\
C. A statement is not admissible under this \\
exception unless its proponent gives to all parties \\
reasonable notice in advance of trial, or during \\
trial if the court excuses pretrial notice for good \\
cause shown, of the substance of the statement \\
and the identity of the declarant. \\
OKLA. STAT. ANN. tit. 12, $\S 2804.1$ (West, \\
Oregon
\end{tabular}




\begin{tabular}{|c|c|c|}
\hline & & $\begin{array}{l}\text { in advance of the trial or hearing, or as soon as } \\
\text { practicable after it becomes apparent that such } \\
\text { statement is probative of the issues at hand, to } \\
\text { provide the adverse party with a fair opportunity } \\
\text { to prepare to meet it. } \\
\text { OR. R. EVID. 803(28); see also } 804(3) \text { (h) (residual } \\
\text { exception for an unavailable declarant). }\end{array}$ \\
\hline Pennsylvania & No & \\
\hline Rhode Island & Yes & $\begin{array}{l}\text { Rhode Island Rules of Evidence } 803(24) \& \\
\text { 804(b)(5) } \\
\text { [Modeled after Federal Rule] }\end{array}$ \\
\hline $\begin{array}{l}\text { South } \\
\text { Carolina }\end{array}$ & No & \\
\hline South Dakota & Yes & $\begin{array}{l}\text { South Dakota Rule 19-19-807 } \\
\text { [Modeled after Federal Rule] }\end{array}$ \\
\hline Tennessee & No & $\begin{array}{l}\text { Committee Note: } \\
\text { There is no residual exception even where } \\
\text { declarants are unavailable. Occasionally, } \\
\text { however, constitutional considerations require a } \\
\text { tribunal permit the accused in a criminal case to } \\
\text { introduce trustworthy hearsay not falling within a } \\
\text { traditional exception. See Chambers v. } \\
\text { Mississippi, } 410 \text { U.S. } 284,93 \text { S. Ct. } 1038,35 \text { L. } \\
\text { Ed. 2d } 297 \text { (1973). See also F. R. Evid. } 804(\text { b)(5). } \\
\text { TENN. R. EVID. } 804 \text { advisory commission's } \\
\text { comment. }\end{array}$ \\
\hline Texas & No & \\
\hline Utah & Yes & $\begin{array}{l}\text { Utah Rule } 807 \\
\text { [Modeled after Federal Rule] }\end{array}$ \\
\hline Vermont & No & \\
\hline Virginia & No & \\
\hline Washington & No & \\
\hline West Virginia & Yes & $\begin{array}{l}\text { West Virginia Rule } 807 \\
\text { [Modeled after Federal Rule] }\end{array}$ \\
\hline Wisconsin & $\begin{array}{l}\text { Yes, but } \\
\text { modified }\end{array}$ & $\begin{array}{l}\text { "Other exceptions. A statement not specifically } \\
\text { covered by any of the foregoing exceptions but } \\
\text { having comparable circumstantial guarantees of }\end{array}$ \\
\hline
\end{tabular}




\begin{tabular}{|c|c|c|}
\hline & & $\begin{array}{l}\text { trustworthiness.” WIS. STAT. ANN. } \$ \S 908.03(24) \text {, } \\
\text { 908.045(6) (West } 2009 \& \text { Supp. 2013). }\end{array}$ \\
\hline Wyoming & Yes & $\begin{array}{l}\text { Wyoming Rules 803(24) \& 804(b)(6) } \\
\text { [Modeled after Federal Rule] }\end{array}$ \\
\hline $\begin{array}{l}\text { District of } \\
\text { Columbia }\end{array}$ & No & \\
\hline Puerto Rico & Yes & $\begin{array}{l}\text { Other exceptions.-A statement having } \\
\text { circumstantial guarantees of trustworthiness, if it } \\
\text { is determined that: } \\
\text { (i) the statement is more probative on the point } \\
\text { for which it is offered than any other evidence } \\
\text { which the proponent may procure through } \\
\text { reasonable efforts, and } \\
\text { (ii) the proponent notified the adverse party } \\
\text { sufficiently in advance his intention to offer the } \\
\text { statement, and the particulars of it, including the } \\
\text { name and address of the declarant. } \\
\text { P.R. R. EVID. 64(B)(5). }\end{array}$ \\
\hline Guam & Yes & $\begin{array}{l}\text { Guam Rule of Evidence } 807 \\
\text { [Modeled after Federal Rule] }\end{array}$ \\
\hline $\begin{array}{l}\text { American } \\
\text { Samoa }\end{array}$ & Yes & $\begin{array}{l}\text { American Samoa Rules 803(24) \& 804(b)(5) } \\
\text { [Modeled after Federal Rule] }\end{array}$ \\
\hline $\begin{array}{l}\text { U.S. Virgin } \\
\text { Islands }\end{array}$ & Yes & $\begin{array}{l}\text { Virgin Islands Rule } \mathbf{8 0 7} \\
\text { [Modeled after Federal Rule] }\end{array}$ \\
\hline $\begin{array}{l}\text { Northern } \\
\text { Mariana } \\
\text { Islands }\end{array}$ & Yes & $\begin{array}{l}\text { Northern Mariana Islands Rule } 807 \\
\text { [Modeled after Federal Rule] }\end{array}$ \\
\hline
\end{tabular}

